\title{
Recientes aportaciones al culto de las aguas en la Hispania romana
}

\author{
J. M. BLAZZUEZ * \\ M. P. Garcia-Gelabert **
}

El culto a las aguas gozó de gran aceptación en la Hispania romana ${ }^{1}$ y antes en la prerromana. Con el estudio del culto a las aguas en época romana, se pueden seguir muy bien la pervivencia de los cultos indigenas y el sincretismo religioso y la aculturación romana de una sociedad indigena, originándose una mixta indígena-romana.

Con esta comunicación tan sólo queremos recoger los últimos testimonios de este culto, que aportan importantes novedades al tema.

CUEVA NEGRA

En los últimos años el yacimiento más importante, vinculado con el culto a las aguas es el de Cueva Negra ${ }^{2}$. Se trata de una cueva con cuatro fuentes en el interior, llena de tituli picti en sus paredes. La cueva

* Universidad Complutense de Madrid.

** Tutora de la UNED.

1 Blazouez, J. M., Religiones primitivas de Hispania; 1. Fuentes literarias y epigráficas. Roma 1962, 167 ss. Id. Die Mythologie der Althispanier, Wörterbuch der Mythologie II. Götter und Mythen im Alten Europea. Stuttgart 1973, passim. Id., Diccionario de las religiones prerromanas de Hispania. Madrid 1975, passim. Id., "Eirheimische religionem Hispaniens in der römischen Kaiserzeit», ANRW II, 18, 1986, 224 ss. Id., Historia de España II. La España romana. Madrid 1982, 297 ss. Id., Primitivas religiones ibéricas, t. Il. Religiones prerromanas. Madrid 1983, 293 ss., Id., Religiones en la España antigua. Madrid 1991, passim.

${ }^{2}$ Varios, "Cueva Negra de Fortuna (Murcia) y sus tituli picti: un santuario de época romana", Antigüedad y Cristianismo IV, 1987. 
estaba vinculada con un balneario, consagrado a la diosa Fortuna Ba/nearis, muy probablemente. Cueva Negra era un santuario, un antrum, usando la terminologia de los antiguos, cuyas deidades más repetidas en las inscripciones, son las ninfas, citadas en tres textos, dos de ellos iguales:

1. NUMPHARUM LATICES / ALIOS RESTINGUITIS / IGNIS ME TAMEN AT FONTES ACRIOR URIT / AMOR.

2. NUMPHARUM LATICES / ALIOS. RESTINGUITIS / ICENES. M.E. TAMEN. AD / FONTES ACRIOR URIT / AMOR.

3. VOTA REUS VENERI NYMPHIS / CONVICIA DONA / NIL PECCANT LATICES PAPHI / EN PLACATO VALEBIS.

También, en los tituli picti se hace mención a las aguas, latices, a las fontes, a las guttae, a Asclepio, dios muy vinculado con las aguas salutiferas.

Las ninfas aparecen citadas como númenes. Un templo a las ninfas nubo en Valencia, templos que no fueron frecuentes. En una inscripción las ninfas van vinculadas con Venus.

El nombre del municipio, al que pertenece Cueva Negra es Fortuna, que seria una Fortuna Balnearis, cuyo establecimiento termal romano se encuentra cerca de Cueva Negra. Precisamente en este pueblo se han conservado restos, hasta comienzos del presente siglo, de un balneario romano, debajo del actual, y se han recogido monedas ${ }^{3}$, ofrendas sin duda a las ninfas del balneario, cuyo templo sería Cueva Negra.

Un dios mencionado en Cueva Negra, asociado con las ninfas es Baccho, dios muy vinculado con ellas, en opinión de Ovidio (Met. 3,253-315), de Horacio (Od. 2,19,1-14) y de Lucrecio (de rer. natu. 4,580-595).

En Cueva Negra, como es frecuente en la religión romana, se da, pues, una asociación de dioses. Zeus, bajo la advocación de Chaoni, aparece citado en el frontispicio de la entrada. También se veneraron los dioses frigios, Cibeles y Atis.

El titulus pictus VI Kaprie, puede tener alguna relación con las fiestas de la Fortuna Balnearis, que debió ser la fiesta más importante de los baños termales de las proximidades de la Cueva Negra.

Amante, M., y Lechuga, M., «Un nuevo hallazgo de denarios romanos republicanos en la provincia de Murcia», Numisma 32, 177-179, 1982, 9-20. 
La religión que se practicaba en Cueva Negra era de salvación, pero como señala A. González Blanco «las categorías que sirven para expresar la reacción de los devotos son formas de vida mental y espiritual de ciudadanos del Imperio y que si las libaciones o los baños no necesitan de teoria que los explique o justifique, desde luego admite "encuadres" y "telones de fondo", no sólo físicos, sino culturales en los que realizarse. Estas contextualizaciones son los textos que estamos considerando". Con el texto de la Eneida, repetido tres veces en Cueva Negra, según la tesis de A. González Blanco, se tiene «el uso consciente de un texto "sacro" para dar sentido a un rito... estamos ante una religión naturalista en su origen, pero contaminada o "convertida" en religión mistérica, y con historicidad de su "mito"".

En Cueva Negra se escribió un poema báquico, que aludia a los poemas alegres, parte importante de la liturgia báquica.

Poca cosa se puede conocer sobre los ritos practicados en Cueva $\mathrm{Ne}-$ gra. Las alusiones, sedibus, vota y scripserunt, son vagas y poco significativas. A. González Blanco es de la opinión que es probable que se diesen los ritos típicos de los asclepieos y que es más que probable que se dieran los ritos de curación en Cueva Negra, cercana a los baños de Fortuna, ya que el lugar se prestaba a ello por la presencia del antrum, rodeado de un recinto, fuente, bosque, etc. Muy probablemente se celebraban con gran solemnidad las fiestas de Fortuna.

Piensa A. González Blanco, apoyado en la calidad paleográfica, y en las inscripciones en verso, que en este templo debieron existir rapsodas que trabajaban al servicio del templo y de los peregrinos, escribas o pictores, encargados de escribir en las paredes los versos.

Los oferentes de Cueva Negra debían ser gentes autóctonas en su mayoria, romanizadas pudientes, desde luego de procedencia no itálica. La crisis de la Anarquia Militar ocasionó el final de las inscripciones, aunque la cueva debió continuar como lugar de culto.

A. González Blanco ha supuesto que el bosque que rodeaba la Cueva Negra era propiedad del santuario, lo cual es muy probable.

Ta! vez Cueva Negra fue un santuario ya en época prerromana, que continuó en época romana, como sucede en otras muchas cuevas santuarios de la región levantina ${ }^{4}$. Mientras no se descubra la favissa, se desconoce el tipo de ofrendas que hacían los devotos.

\footnotetext{
${ }^{4}$ BLȦZquez, J. M., Primitivas religiones, 204 ss.
} 
Recientemente M. Mayer ${ }^{5}$, con motivo de estudiar una inscripción de Cueva Negra que dice: MONTIS IN EXCELSOS / PHRUGIA NUMINA / TEMPLIS FIDELIBUS INSTRU / CTIS ALTIS. CONSTITUERE DEIS / HOC ETIAM L. OCULATIUS. RUSTICUS / ET. ANNIUS CRESCENS / SACERDOS. ASCULEPI / EBUSITANI SCRIPSERUNT / VI. K. APRIL, recuerda que A. V. Stylow y él propusieron que esta inscripción fuera de un sacerdos Asculepi ebusitani, que el Esculapio mencionado en este epígrafe fuera en realidad el Eshmun púnico y que el Aesculapius Ebusitanus de Cueva Negra sería un caso de pervivencia de una deidad púnica, semejante al Hércules gaditanus, interpretatio de un culto al Melqart gaditano. M. Mayer en su trabajo estudia la razón de la presencia de un sacerdos Asculepi ebusitani y en segundo lugar hasta qué punto Eshmun subyace en este Esculapio. Piensa este autor que las inscripciones son parte del ritual, lo cual es muy probable, y mejor de unos ritos celebrados a fecha fija, el 27 de marzo. La inscripción está dedicada por dos personajes Annius Crescens y Oculatius Rusticus, que son forasteros, lo que haría pensar en cierta colegialidad. Si ebusitani se refiere a Asculepi sólo lo sería Annius, que es el sacerdos. Si ebusitani se refiere a los dos dedicantes, indicaria el origo de ellos. Los Oculatii están bien documentados en Ebussus. M. Mayer pensó, en un primer momento, en un origen ebusitano de ambos dedicantes, aún refiriendo ebusitani a Asculepi. Este autor sugiere que los oferentes de la inscripción sean duoviri de Ebussus y uno de ellos sacerdos de Asculepi, que llegarian a Cueva Negra en misión oficial. Un culto celebrado ciclicamente pudo ser encargado a dos forasteros ilustres, o que fueran en cumplimiento de un voto.

M. Mayer, después de examinar los nombres de los oferentes, se inclina a que el hecho de que en la Cueva Negra sean dos ebusitanos: $A$. Annius Crescens sacerdos Asculepi. Ebusitani y L. Oculatius Rusticus, con el mismo nomen y praenomen de los Oculatii Recti que en la propia Ibiza rinden culto a luno Regina (que M. Mayer identifica, creemos muy acertadamente, con Tanit), nos parece muy significativo y nos viene a confirmar lo que indicábamos al principio: seguramente se manda, en forma oficial, a dos personajes desde Ebussus, a la Cueva Negra, la cual independientemente de su posible propio contenido púnico, está en el área de influencia de Carthago Nova, que presenta innegables paralelismos de pervivencias púnicas con Ebussus. Estos paralelismos serian puestos de relieve por la mención de Esculapio Ebusitano por parte de un sacerdote, A. Annius Crescens y se nos evidencia, además por el hecho de que el

\footnotetext{
5 "La pervivencia de cultos púnicos: el documento de la Cueva Negra (Fortuna, Murcia)», L'Africa Romana, VII, 2. Sassari 1990, 695 ss.
} 
otro personaje fuera L. Oculatius Rusticus, emparentado con una de las familias más notables de Ebussus.

Termina M. Mayer su importante trabajo indicando que «para Carthago Nova y para Ebussus, la Cueva Negra establecería un elemento puente de relación y nos permitiría ver como para estas ciudades, las pervivencias púnicas se manifestarian en una forma semejante a Carthago".

Lo que no cabe duda es que Cueva Negra fue un templo de las ninfas que extendía su culto más allá de la región en que estaba colocado.

DIOSES LUSITANOS DE CARÁCTER ACUÁTICO

J. Encarnaçao ${ }^{6}$ ha publicado un trabajo sobre las divinidades indígenas en Lusitania, entre las que se encuentran las siguientes de carácter acuático: Araco Aranto Niceo, vagamente relacionada con las aguas. La dedicatoria está hecha por una indígena romanizada, lulia Maxima, hija de Auvo; Banda con 11 inscripciones, en Lusitania, que para nosotros es una diosa asimilada a Tutela y de carácter acuático, por la razón que se indicará más adelante; Mercurio Augusto Aquaeco; Nabia vinculada con divinidades acuáticas; y Remetibus Aug(ustis).

EL CULTO A LAS AGUAS EN LA RIOJA

R. M. Valdivieso ${ }^{7}$ menciona algunas divinidades, que podían relacionarse con las aguas, entre las que cabe citar a Caldo, Obiona, Varna y Vurovinis.

\footnotetext{
" «Divinidades indígenas de Lusitania», Conimbriga 26, 1987, 5 ss.

${ }^{7}$ Religiosidad antigua y folklore religioso en las sierras riojanas y sus aledaños. Logroก̃o $1991,38$.
} 
BALNEARIOS GALAICOS

F. Díez de Velasco ${ }^{8}$ ha estudiado los balnearios y los dioses de las aguas termales en Galicia romana, que superan la veintena y son importantes por la riqueza y variedad de su epigrafía, trabajo que resumimos.

La toponimia hispana indica bien a las claras la importancia del termalismo en esta región. Al norte del Duero cinco ciudades llevan topónimos vinculados con las aquae, lo que señala que la localización del hábitat urbano está en función de la presencia de aguas termales. La presencia de topónimos modernos o Caldas y sus derivados, en número de siete, que descienden directamente de Aquae Caldae; o de baños y sus derivados en número de ocho, procedentes de la palabra romana Balinea, prueban la gran importancia que el termalismo alcanzó en época romana. Se documentan en el norte de las provincias hispanas de Lusitania y de la Tarraconense 26 establecimientos termales abiertos en época romana, de los que 17 han proporcionado epigrafía votiva.

La finalidad de los balnearios era curativa. Los datos de que dispone el investigador sobre los balnearios galaicos son pocos en número. Edificios hubo en Baños de Bande, Baños de Molgas, Caldas de Canaveres, Caldas de Vizella, San Vicente de Piñeiro, Río Caldo, Caldas de Cuntis y Lucus Augusti en restos empotrados en el balneario y canalizaciones de Baños de Molgas y Mondariz.

Se ofrecian a las divinidades termales, como ofrendas, monedas, que eran parte del ritual. En Caldas de Cuntis se recogieron 500, fechadas entre los años de los gobiernos de Tiberio y Constantino II. Las monedas del balneario de Caldas de Vizella se fechan en el siglo I.

Las aguas termales eran sagradas (PLIN. 31,2,4) tanto para algunos romanos, como para los pueblos primitivos, se creía que en los manantiales termales vivian seres sobrenaturales que participaban en las curaciones.

" "Balnearios y dioses de las aguas termales en Galicia romana", AEspA 58, 1985, 6998; Id., «Divindades indixenas das augas termais no extremo Occidente Hispano", Larouco I, 1991, $53 \mathrm{ss} ;$ Id., "Divinités des eaux thermales dans le Nord-Ouest de la Provincia Tarraconensis et dans le Nord de la Provincia Lusitania: une approche au phénomène du thermalisme romain dans l'Occident des Provinces Ibériques", Les Eaux thermales et le culte des eaux en Gaule et dans les provinces voisines (Aix-les-Bains 1990). Tours 1992 (págs. 133-149); Id., "Invocaciones a Isis en las ciudades de aguas (aquae) del Occidente romano. Isis, nuevas perspectivas". Madrid 1988, Homenaje a Álvarez de Miranda (en prensa). 


\section{DIOSES TERMALES INDÍGENAS}

Son tres los documentados en Galicia:

Bormanico (dos veces en Caldas de Vizella). Es un dios autónomo propio de las zonas celtizadas de Europa, cuya raíz indoeuropea bher = hervir, reaparece en ocho topónimos de Hispania ${ }^{9}$.

Coventina (Guitiriz y Santa Cruz de Lugo). Es una diosa propia de los celtas brigantes ${ }^{10}$.

Edovio (Caldas de Reyes), interpretado como «el que calienta» ${ }^{11}$.

- Band - diosa bien documentada en Hispania, que muchos autores creen ser una diosa de carácter acuático ${ }^{12}$.

Al norte del Duero se han localizado los únicos teónimos indígenas relacionados con las aguas, los devotos dedicaban su culto a los dioses indigenas en estos cinco casos, lo que indica una aculturación más débil de estas regiones que la del resto de Hispania. Este culto a las aguas era ya anterior a la presencia romana, como lo indica las llamadas piedras formoras, interpretadas recientemente (1983), como pertenecientes a termas. Los devotos eran peregrinos en el caso de Edovio y de Bormanico. La segunda inscripción dedicada a este dios lo es por un ciudadano romano y se señala además su procedencia de Uxama.

\section{DEIDADES SINCRETISTICAS}

Ninfas.

Lupianiis (Tagilde), son ninfas indígenas.

Salutatibus (Bóveda). Estas ninfas llevan un epíteto romano.

\footnotetext{
${ }^{9}$ Blázouez, J. M., Religiones primitivas, 171 ss. ld., Diccionario, 48 ss. Id., Primitivas religiones, 293.

${ }^{10}$ Blázquez, J. M., Religiones primitivas, $190 \mathrm{ss}$. Id. Diccionario, $55 \mathrm{ss}$. Id. Primitivas religiones, 293.

${ }^{11}$ Blázquez, J. M., Religiones primitivas, 175 ss. ld., Diccionario, 93 ss. ld., Primitivas religiones, 294.

${ }_{12}$ Blazquez, J. M., Religiones primitivas, 51 ss. Id., Diccionario, 93 ss. Id., Primitivas religiones, passim.
} 
Tutela. Su invocación podía tener carácter termal, si aparece en balnearios. Protegía los lugares, los grupos humanos o los individuos.

La confirmación de que la diosa Band se asimila a Tutela y ésta a la ninfa acuática, es la pátera de la antigua colección Calzadilla, donde se representa a Bandua Araugelensis bajo la imagen de Tutela y una ninfa junto a una fuente en la parte superior ${ }^{13}$.

Las ninfas fueron las diosas más invocadas en los balnearios, veinticinco veces sobre treinta y ocho. En seis balnearios se las invoca en exclusiva y en dos en mayoría. Varian de unas inscripciones a otras la grafía. Así se escribe: Nimphis, Nymphis, Nymfis, Ninphis, Nimpis.

Personajes orientales fueron los devotos de estas ninfas. En Chaves dos inscripciones llevan nombres de procedencia oriental; en una se trata de un liberto imperial, y en la segunda de un ciudadano romano. En el culto a las ninfas sin epiteto indígena se detecta un caso de sincretismo entre diosas indígenas y romanas, que indica un avance de la aculturación por parte de las poblaciones indígenas. Piensa F. Díez de Velasco, a quien seguimos, que en el caso de Chaves el culto a las ninfas gozó de especial prestigio, pues hasta los personajes imperiales lo practicaban, hecho que se repite en el culto a Bormanico.

La mayoría de diosas de nombres romanos de las inscripciones recogidas en los balnearios no son de carácter abstracto, las aquis eletesibus cie Retortillo y la Fons de Boñar se relacionan con una fuente concreta. F. Diez de Velasco es de la opinión de que la Salus de Baños de Montemayor, o de Baños de Valdelagarza, tienen un carácter diferente del que ofrece la Salus en la religión romana. En Baños de Montemayor Salus equivalía a una ninfa, como lo prueba el caso de la Salus Umeritana, personificación de una fuente.

FONS

De Boñar se conoce un testimonio de culto a Fons Sag. Se trata de una deidad indigena, a la que un romano rindió culto.

${ }^{13}$ Blazzquez, J. M., Diccionario, Id., Primitivas religiones, 263, $307 \mathrm{~s}$. 
DEIDADES ROMANAS

En Termañes recibió culto Fortuna balnearis, equivalente a Fortuna salutaris.

ESCULAPIO-SALUS-SERAPIS-ISIS (LEÓN)

A Esculapio, dios de la medicina, se le invocaba en cualquier enfermedad. Salus se relaciona con aguas curativas en once casos en Hispania. Isis está en relación con el balneario de Caldas de Montbuy. No es totalmente seguro que hubiera un balneario en legio VII Gemina, aunque es muy probable.

\section{CRISTIANIZACIÓN DEL CULTO A LAS AGUAS}

El cristianismo luchó contra el culto a las aguas sin conseguir ningún resultado positivo. Su culto fue condenado por Martín de Braga en su De correctione rusticorum, 6,8,16, quien afirma que en las fuentes habitan los demonios, y que se arrojaba pan a las fuentes, como parte del ritual.

Muchos lugares paganos, de culto a las aguas, fueron después cristianizados ${ }^{14}$.

DEDICANTES A LAS DEIDADES INDIGENAS

Los dedicantes llevan nombres indígenas en los casos de Bormanico y Edovio, y las inscripciones se fechan en el siglo .

\footnotetext{
${ }^{14}$ Blázquez, J. M., Religiones primitivas, $39 \mathrm{~s}$.
} 
Uno de los epígrafes de Bormanico de Caldas de Vizella está dedicado por un romano, según los tria nomina, cuyo padre era un indígena.

Sólo en Galicia, de toda Hispania, se documentan teónimos indígenas, de aguas termales, y en cuatro casos son nombres celtas.

DIOSES ROMANOS

Sólo se registran en la parte sur de Galicia.

\section{NINFAS}

Su nombre se registra en 16 de 23 inscripciones halladas en balnearios. Este nombre se vincula a aguas termales en nueve casos, siete de ellos se encuentran en el Conventus Bracaraugustanus.

Piensa Diez de Velasco, que los dioses indígenas de tipo celta son sustituidos por cultos como el de las ninfas, que por un fenómeno de sincretismo ocupan el lugar de las deidades autóctonas, produciéndose una ósmosis entre el elemento romano y el indígena y originándose una sociedad mixta, celta-romana.

INVENTARIO DE LOS BALNEARIOS DEL NOROESTE PENINSULAR

Banhos de Ariolo (Portugal)

Con probables restos de termas romanas.

Baños de Bande (Orense)

Es la posible mansión de aquae querquernae, citada por Plinio $(3,28)$, por Ptolomeo $(2,6,46)$, por el Itinerarium Antonini $(428,2)$, y por el Rave- 
nate $(4,45-320,3)$, etc. Los restos que se conservan son pocos. Se conocen ofrendas de monedas y un ara dedicada a las ninfas por un indígena de nombre Boelius.

Baños de Cuntin (Lugo)

Es la antigua aquae quintiae del Itinerarium Ast. (2) y la Udata Kouintina de Ptolomeo $(2,6,27)$.

Baños de Molgas (Orense)

Probablemente es la mansio salientibus (It. Ant. 438,4; Rav. 4,45-320,5). La antigua aquae geminae, era un balneario romano del que se conservan restos de canalizaciones, monedas, fibulas de bronce, etc., y una inscripción dedicada a las ninfas por Aurelius Flavius Transcatanus, hoy conservada en una iglesia próxima.

Baños de Río Caldo (Orense)

Probablemente es la mansión de aquis originis del Itinerarium Antonini $(428,1)$ y del Ravenate $(4,45-30,2)$ que ha proporcionado algunos restos romanos.

Bem-Saude (Portugal)

Con ara consagrada a las ninfas aparecida a dos kilómetros del balneario.

Boñar

Esta fuente termal dio un ara dedicada a Fons, consagrada por un aquilegus, oficio que consistía en buscar manantiales.

\section{Bóveda}

En una fuente de virtudes curativas apareció un ara, fechada en el siglo II, consagrada por Sulpicia Saturnina a las ninfas. 
Caldas de Canaveses (Oporto)

Habia en esta localidad un antiguo balneario romano, con piscinas, mosaicos y otros restos del edificio.

Caldas de Cuntis (Pontevedra)

Probablemente es la aqua calidae de Ptolomeo $(2,6,24)$. En esta localidad hubo un balneario romano en el que aparecieron unas 500 monedas romanas y dos aras dedicadas a las ninfas por Antonius Florus. Las ofrendas de monedas a las ninfas en los balnearios formaba parte, como indicamos, del ritual. Se fechan estas monedas desde la época Julio-Claudia al Bajo Imperio; por lo tanto el balneario estuvo abierto toda la época imperial. En las proximidades se hallaron dos altares consagrados a las ninfas.

Caldas de Lafoes (Portugal)

Tenía un balneario con dos piscinas. Una inscripción de A. Plautius Decianus se refiere a la construcción de las termas. Una segunda está dedicada a Mercurius Augustus Aquaecus.

Caldas de Reis (Pontevedra)

Se la identifica con aquae celenis del Itineraium Antonini $(430,3)$ y del Ravenate $(4,43-321,8)$. En los cimientos del balneario se han recogido monedas. Una ara hallada en él está dedicada a Edovio por un indígena de nombre Adalus, hijo de Cloutius.

Caldas de Taipas (Portugal)

Cerca del Balneario, en $S$. Joao de Ponte, se encontró un ara consagrada a las ninfas por G. Sulpicius Festus.

Caldas de Vizella (Portugal)

Este balneario tenia once piscinas de varios tamaños con compartimentos abovedados y mosaicos. 
Recientes aportaciones al culto de las aguas en la Hispania romana

Una inscripción dedicada a Bormanico lo fué por el indígena Medamus Camalus. Una segunda inscripción menciona al mismo dios. El dedicante era C. Pompeius Gal (eria tribu) Caturonis Motugenus Uxamensis. El dedicante es un romano descendiente de un indigena.

Otras inscripciones, halladas en los alrededores del balneario, están dedicadas a las ninfas: una lo fué por Antonia Rufina.

\section{Caldelas (Portugal)}

En este yacimiento se halló también un ara dedicada a las ninfas.

\section{Chaves (Portugal)}

Se ha identificado este balneario con Aquae Flaviae, con Aquas o Ad Aquas del Itinerariun Antonini $(422,6)$ y del It. Ast. (4) y con la Udata Laia de Ptolomeo $(6,69,39$ ) y con la Aquae Flaviae de las inscripciones (C.I.L. II, 4779-4783,2477). Probablemente es el Municipium Flavium Aquiflaviense. Dos inscripciones están dedicadas a las ninfas, una de ellas es dudosa. La otra está consagrada por Dionysius, que fué liberto imperial. La tercera inscripción está en honor de Tutela (Isis).

\section{Guitiriz (Lugo)}

En este balneario se halló la inscripción dedicada a Cohvetene.

\section{Legio VII Gemina (León)}

Se conservan varias inscripciones dedicadas a las ninfas. Una inscripción a las ninfas está dedicada por $T$. Pomponius Proculus Vitrasius Pollio y su esposa Faustina (C.I.L. // 5679), consagraron otra inscripción a las Nymphes Griselicis en Gréoux, Francia. Un legado de la Legio VII Gemina, L. Terentius Homullus Iunior (C.I.L. II, 5084) dedicó dos altares a las Nymphis Fontis. Un Imaginiffer de la Legio VII Gemina, de nombre Q. Cornelius Anteros costeó una inscripción, sólo conocida por el Codex Parisinus Latinus (2036) en honor de las Nimphis. Dos personajes de familia senatorial del siglo II, L. Cassius Paullus Augustanius Alpinus Bellicius Sollers y M. Cassius Agrippa Sanctus Paullinus Augustanius Alpinus de- 
dicaron una inscripción a Esculapio-Salus-Serapis-Isis en la Legio VII Gemina.

Lucus Augusti (Lugo)

Se conservan restos de un balneario con cámaras romanas cuadradas o abovedadas. Se tienen noticia de otras dos cámaras de similar factura a las anteriores.

Se han hallado inscripciones dedicadas a dos deidades supuestamente acuáticas: Labo paraliomego consagrada por Caelius Rufinus, y a Tutela.

\section{Mondariz}

Se han descubierto restos de pilas y de cañerias antiguas que debieron pertenecer a un balneario romano.

Orense

Se encontró, junto al balneario de Orense, una inscripción dedicada a las ninfas, un altar dedicado por Calpurnia Abana. Estuvo frecuentado desde el siglo I al IV.

San Vicente de Piñeiro

Aquí existió un balneario de época romana, que se surtía de aguas de un manantial sulfuroso.

Santa Cruz de Loyo (Lugo)

En esta localidad se recogió un ara consagrada a Cuhveberralocegu por Flavius Valerianus. Las aguas de este balneario no eran termales, poseian sólo propiedades minerales y curativas. Probablemente los visitantes se bañaban en las aguas curativas. 


\section{Tremañes}

Se hallaron unos baños con argamasa de tipo romano. Una inscripción dedicada a la Fortunae Valneari por T. Pompeius Peregrinanus. F. Díez de Velasco es de la opinión que el monumento de Santa Eulalia de Bóveda en un ninfeo, o sea, un templo consagrado a las ninfas, con relieves en el vestíbulo romano de enfermos, que acudian buscando la salud corporal, lo cual es muy probable.

\section{BALNEARIOS DE LAS ACTUALES PROVINCIAS ESPAÑOLAS DE CÁCERES Y SALAMANCA}

\section{Retortillo (Salamanca, España)}

Se han hallado restos de tegulae, de cerámica y monedas. Una inscripción está dedicada a las aquis eletesibus.

\section{Baños de Montemayor (Cáceres, España)}

Se utiliza en la actualidad para el baño aún la piscina romana; siete inscripciones están dedicadas a las ninfas: seis a las ninfas caparenses; una a la ninfa de la fuente y tres a Salus.

Baños de Ledesma (Salamanca, España)

Se conserva una gran sala termal romana.

\section{Baños de Valdelagarza (Cáceres)}

Una inscripción está consagrada a Salus. Hay restos romanos.

En el culto termal de esta región hispana los dioses romanos desempeñaron un papel secundario. Fortuna Balnearis se documenta en Tremañes, en Cueva Negra y en Duratón (Segovia). En teónimo Mercurius Augustus Aquaecus de Caldas de Lafoes no es de lectura segura. Podía 
referirse a una fuente termal. No es totalmente seguro que la dedicatoria a Isis de Chaves se relacione con un balneario cosmopolita por el número y procedencia de los visitantes, bien comunicado donde era fácilmente posible la invocación a la diosa egipcia.

No se puede dudar de la importancia del culto termal en el NO de Hispania; como lo indican las inscripciones y la documentación arqueológica.

Las aguas obraban la curación de los devotos por su carácter sagrado debido a los dioses que habitaban en ellas. A influjo humano se debian, en las inscripciones, la escritura, el uso de la lengua, de las invocaciones y muchas veces el teónimo nimphis. Probarian todos estos elementos un grado de aculturación relativamente elevado. 


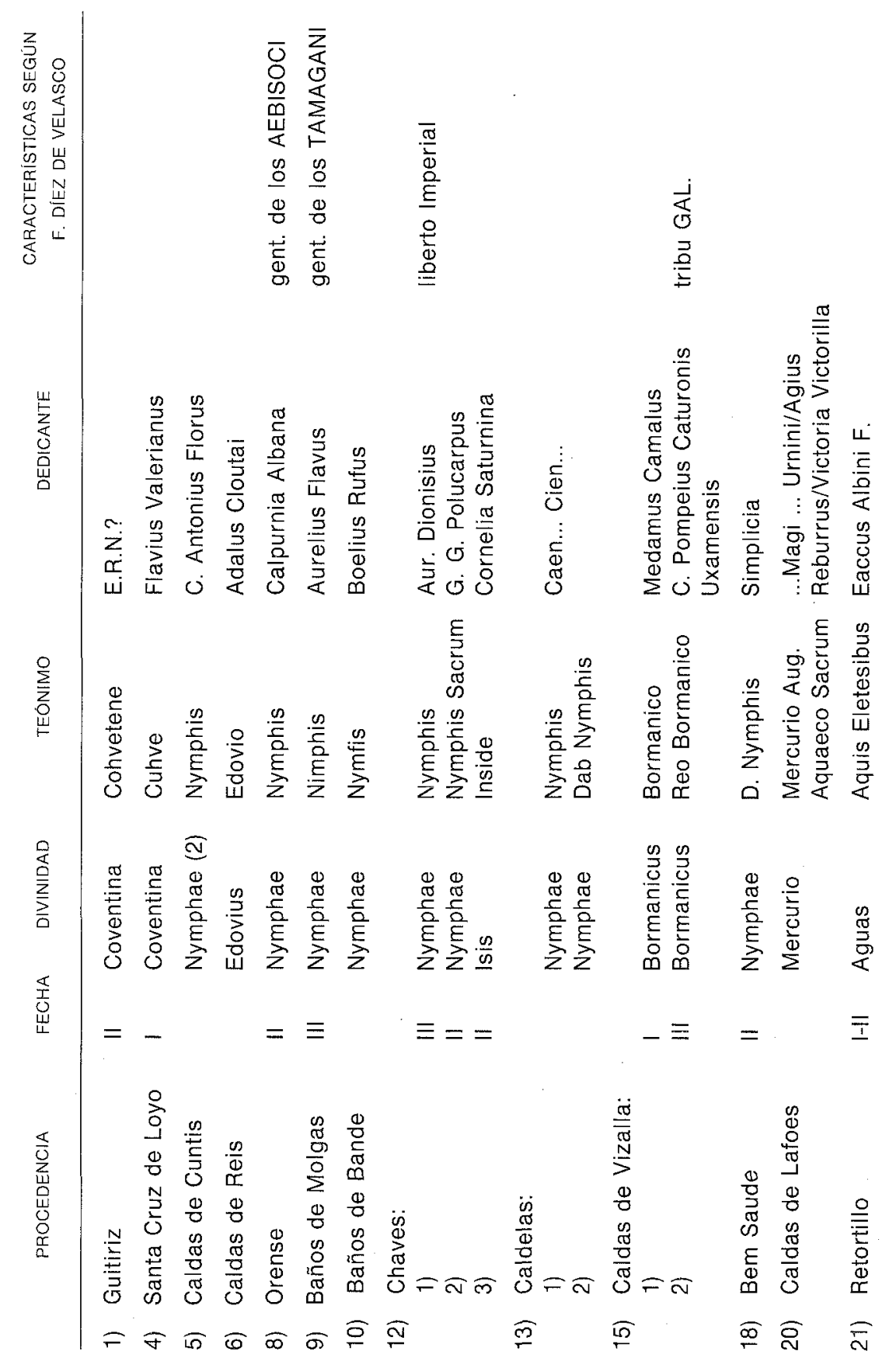




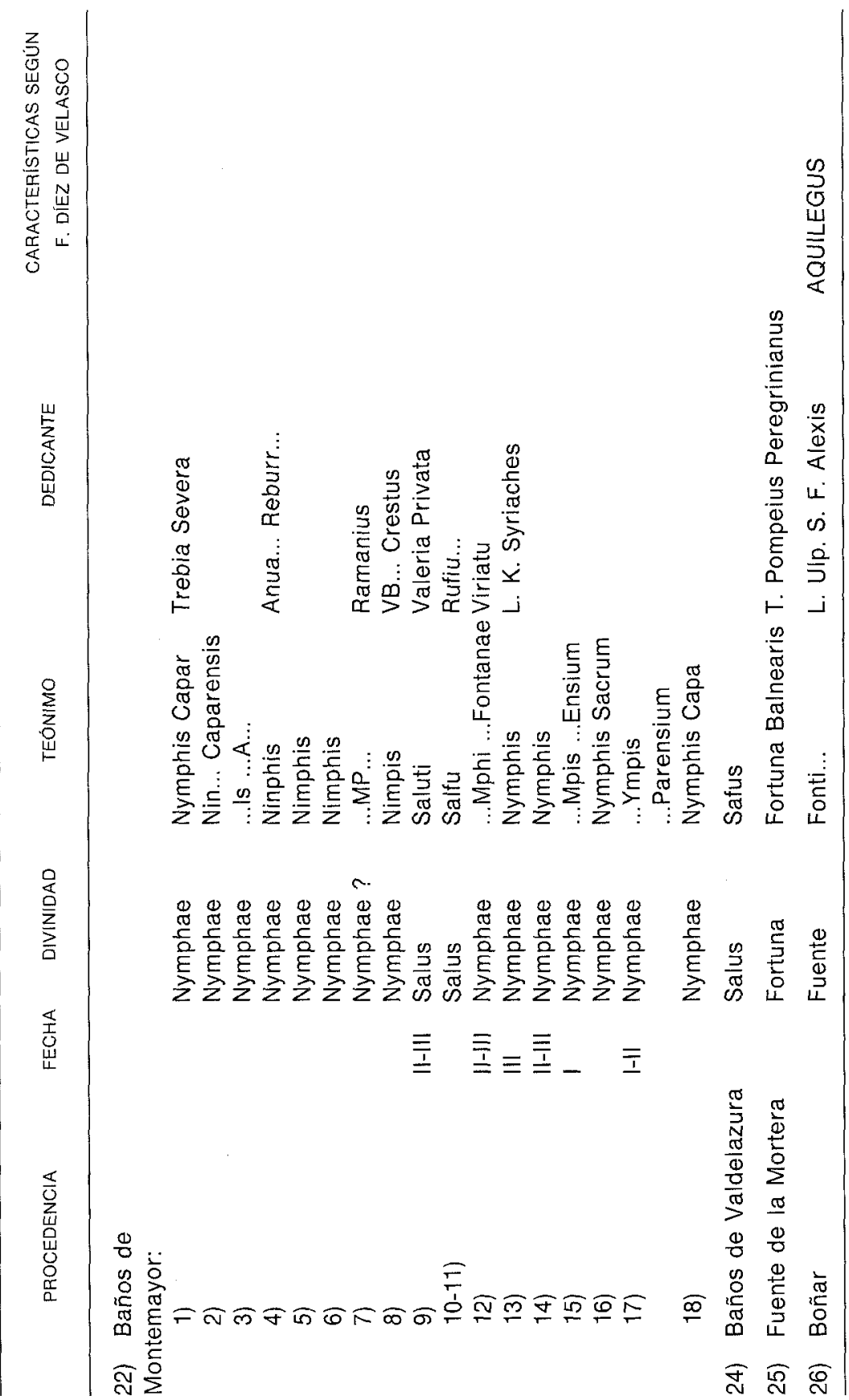


F. Diez de Velasco ${ }^{15}$ ha estudiado recientemente de un modo exhaustivo los Balnearios y divinidades de las aguas termales en la Península Ibérica en época romana. En este importante estudio se llega a conclusiones de interés. Comienza su estudio, después de los prolegómenos, con unas páginas consagradas a los dioses indígenas de carácter acuático, algunos ya mencionados en páginas anteriores: Bormanico, Coventina, y las numerosas diosas compuestas por el sufijo Band-. Otros teónimos indigenas como Edovio de Caldas de Reis; Airo de Uclés ${ }^{16} \mathrm{O}$ Celiborca ${ }^{17}$ de Villasbuenas de inscripciones vecinas o fuentes, Laho Paraliomego de Lugo ${ }^{18}$, Ameipicer ${ }^{19}$, Aponiano Poliscinio, Sandaovimumburo, todos ellos de carácter muy dudoso. El celtismo del culto a las aguas en la Hispania Indoeuropea nos parece seguro. Las divinidades indígenas frecuentemente se ocultan bajo una denominación romana por el fenómeno de sincretismo, tan propio de todas las religiones de la antigüedad, como las mencionadas Nymphae Caparenses ${ }^{20}$ de Baños de Montemayor, la fuente Amevi ${ }^{21}$ de León, las Ninfas Lupianas. El epíteto Salutatibus de Bóveda, indica el carácter terapéutico de estas diosas. En el culto a las ninfas se mezcla un culto indígena, con otro romano. Las ninfas son las diosas de cada fuente, unas veces llevan epítetos y otras carecen de él. Del culto a las Aquis sólo se documentan dos testimonios en Hispania, encontrados en los balnearios de Retortillo y Caldas de Monchique. En ambos se especifica el carácter sagrado del culto. A Fons se conservan nueve documentos. Este culto en ambiente termal se atestigua en Boñar y en Baños de Montemayor, y quizá vinculado a los balnearios en Caldas de Monte Real y Escaña. Los restantes testimonios se relacionan con fuentes salutíferas (Feria, Bencatel), o con un edificio (BurguiIlos). Se ha pensado que este culto a Fons se vincularia con el dios latino Fonto-Fontano. Una de las inscripciones de Baños de Montemayor se dedica a Fontana y una segunda a las ninfas. En Feria y Bencatel se tributaba culto a Fontana y a Fontano, lo que parece indicar que el sexo del dios era indeterminado.

\footnotetext{
${ }^{15}$ Madrid 1987. Editorial de la Facultad de Geografía e Historia de la UCM (Microficha).

${ }^{16}$ Blázquez, J. M., Religiones Primitivas, 167; Id., Diccionario, 30.

${ }_{17}$ Blazquez, J. M., Religiones Primitivas, 173; Id., Diccionario, 55; Id., Primitivas religiones, 480 .

${ }^{18}$ Blazquez, J. M., Religiones Primitivas, 139; Id., Diccionario, 137; Id., Primitivas religiones, 301, 304 .

${ }^{19}$ Blázquez, J. M., Religiones Primitivas, 169; /d., Diccionario, 25.

${ }^{20}$ Blazquez, J. M., Religiones Primitivas, 199; Id., Diccionario, 52; Id., Primitivas religiones, 293.

${ }^{21}$ Blázquez, J. M., Diccionario, 25.
} 
En Hispania se conservan doce testimonios del culto a Salus, de los que dos se relacionan con balnearios (Baños de Montemayor y Caldas de Montbuy). En otro, Salus Umeritana, su relación con las aguas es clara, a juzgar por la representación. Tutela también sería una deidad relacionada con las aguas en Hispania en determinados casos. Las ciudades hispanas llamadas Tudelas, vinculadas con el teónimo Tutela, están todas en el norte de la Península lbérica y próximas a rios. Tutela se la invocó en lugares con aguas termales como Alhama de Aragón (Aquae Bilbilinanorum) y Chaves (Aquae Flaviae).

Entre los dioses romanos, cuyo culto se vinculaba con aguas termales, cabe recordar a Apolo (Caldas de Malavella, Montbuy y Chaves), cuyo carácter de dios del calor y de la luz le hace muy propio como protector de las aguas termales.

Fortuna Balnearis se relaciona muy probablemente con las aguas salutiferas. Su culto está atestiguado en Tremañes y Duratón, y seguramente en la Fortuna de Murcia, donde existió un balneario romano, con un antrum en las proximidades.

A luno Regina se dedicó un ara en el balneario de Alange. En Caldas de Montbuy apareció una inscripción dedicada a Minerva, en relación con las aguas salutiferas. Inscripciones de Caldas de Montbuy, Chaves y quizá de Legio VII Gemina ponen en relación a Isis con las aguas; en los dos primeros casos la dedicante es una mujer. En el tercero Isis va asociadá a Serapis, Esculapio y Salus. Estos dos últimos dioses están relacionados con las aguas salutíferas. Quizá, Esculapio podia estar vinculado con aguas termales en Nescania, León y Caldas de Vizella. Mercurio en relación con aguas termales se atestigua en Caldas de Reis, Caldas de Vizella y Caldas de Lafoes. Silvano solamente aparece en el contexto termal en Chaves.

El culto a las aguas en Galicia se caracteriza por la hegemonía del culto a las ninfas, en once lugares; por la importancia de los cultos indigenas, en cinco invocaciones; por la nula presencia de los cultos romanos; por el carácter concreto de este culto; por la importancia de este culto desde época prerromana, potenciado por los romanos y por el carácter especifico del culto a las aguas.

Las características del culto en Lusitania señaladas por F. Díez de Velasco, son las siguientes: importancia del balneario de Montemayor; importancia del culto a Salus; dos documentos del culto a las aguas divinizadas, únicos en Hispania; existencia del culto a Fons Fortuna; ausencia del culto a divinidades salutiferas romanas, salvo en el caso de Alange.

En la provincia Tarraconensis se distinguen varias zonas en 10 referente al culto a las aguas. En la zona Noroeste se han hallado dos dedi- 
catorias a Fortuna Balnearis, costeadas por ciudadanos romanos. Se documentan divinidades indigenas de las aguas. En dos casos (Pátera de Otañes y Legio VII Gemina) se rindió culto a Salus con caracteristicas romanas. En Legio VII Gemina el culto a las ninfas es romano, y en el resto de la zona, indígena; pervive, pues, lo indigena frente a lo romano.

La segunda zona es el Valle del Ebro. En ella sólo se conservan dos testimonios del culto a las ninfas: en Leyre en relación con el balneario de Tiermas, y el culto a Tutela en Alhama de Aragón. En la primera inscripción el dedicante es un indígena romanizado, y en el segundo se desconoce su status social.

La tercera región es el Valle de Arán, que ha proporcionado un ara consagrada a las ninfas.

En el conventus de Tarraco está atestiguado en los balnearios de Montbuy y en Caldas de Malavella un culto de tipo romano, con cuatro inscripciones dedicadas a Apolo y una a Minerva; una a Salus y otra a Isis respectivamente. Los devotos son romanos. En Montbuy algunos dedicantes llevan nombres orientales. La dedicante de Isis es una liberta. Estos dioses que recibian culto en estos dos balnearios, eran simplemente dioses sanadores, y no representan a la fuente termal como en Galicia y en Lusitania.

En la Bética sólo se atestigua un dios, luno, asociado con un balneario en Alange. Su culto era del tipo del de Caldas de Montbuy o de Caldas de Malavella.

Los testimonios de las divinidades medicinales-termales se agruparon, pues, en la zona norte y oeste, que estaban menos romanizadas. Hay que tener presente que Roma nunca se propuso romanizar a las poblaciones indigenas, sino explotarlas, como resultado de esta explotación llegó la aculturación ${ }^{22}$. Los dedicantes solian ser gentes de baja condición, libertos, como en Caldas de Montbuy.

F. Díez de Velasco estudia también el culto a las aguas como fenómeno sincretístico y de aculturación.

En el noroeste hispano se documentan dedicatorias a dioses indigenas prerromanos junto a invocaciones a las ninfas. Las ninfas van acompañadas de epítetos tópicos (caparenses, aquae, eletenses) ${ }^{23}$, de carácter

\footnotetext{
22 Blazquez, J. M., Nuevos estudios sobre la romanización. Madrid 1989, 99-145.

23 Blazquez, J. M., Religiones primitivas, 175, 202; Id., Diccionario, 18; Id., Primitivas religiones, 393, 304 .
} 
mistico que recalcan el carácter acuático (ninfas lupianas) ${ }^{24}$, y naturalistas (fons amevi), todo lo cual indica un fuerte sincretismo, como fenómeno de la aculturación de estas poblaciones. Empieza por la latinización de los teónimos indigenas. Poco a poco la aculturación avanza como en las inscripciones de Bormanico. El segundo paso es la interpretatio romana, por el que se asocia un dios indigena a otro romano, con el que presenta algún parecido según la interpretación romana, como en la inscripción de Salus Umeritana, Ninfae Fontis Amevi, Caparensium o Lupianae. Es acertada la opinión de F. Díez de Velasco de que la interpretatio es romana, pero también céltica, y de que el dios romano se adaptó a la situación nueva. Se asimilan el dios indígena y el romano, pero pueden superponerse nuevas funciones al numen romano o modificar sus funciones o potenciar alguna. Se observa, como en África, una contaminación religiosa. Se da una adaptación a las nuevas necesidades. Las ninfas del Conventus Bracarensis no son las mismas ninfas romanas; los romanos potenciaron la aceptación de su nombre. Se ha pensado que los cambios de nombres se deben a un intento indígena de hacer comprensible a los romanos sus divinidades (Lambrino). Se dio una ósmosis entre romanos e indígenas (Lambrino), y la aparición de la sociedad céltico-romana en el noroeste peninsular (Etienne). Hay un fenómeno de aculturación religiosa.

\section{ORGANIZACIÓN DE LOS BALNEARIOS}

Se conoce bien el funcionamiento de un balneario, en la ley de Vipasca, localidad de un distrito minero lusitano, de época de Adriano. Es un balneario de tipo higiénico. En los balnearios de carácter salutífero existían días especiales para tomar los baños rituales. La propiedad de los balnearios podia ser privada, municipal o imperial. Las inscripciones hispanas mencionan el oficio de zaori, aquilex y en Burgillos el de curator balinei probablemente en relación con la construcción del edificio. Las inscripciones halladas en Archena y Tijola citan la construcción de unas termas que no necesariamente serian medicinales.

\footnotetext{
${ }^{24}$ Blázquez, J. M., Religiones primitivas, 173; Id., Diccionario, 120; Id., Primitivas religio-
} nes, 483. 
1. CATÁLOGO DE CIUDADES DE AGUAS (lámina 1)

\section{Alhama de Aragón (Zaragoza)}

Es probablemente la Aquae Bilbinitanorum y conservaba vestigios en el siglo $x \mid x$ de las termas. El agua salía a una temperatura de $34^{\circ}$. En esta ciudad había un ara en honor de Deo Tutel/Genio loci. El topónimo alude a un lugar de aguas. La epigrafía que ha dado la ciudad parece aludir a la existencia de balnearios en ella.

Baños de Bande (Orense)

Es la mansio aquae originae o aquae Querquernae de Plinio $(3,28)$, de Ptolomeo $(2,6,46)$, del Itinerarium Antonini $(428,2)$, del Ravenate $(4,45)$ y del C.I.L. // 2477.

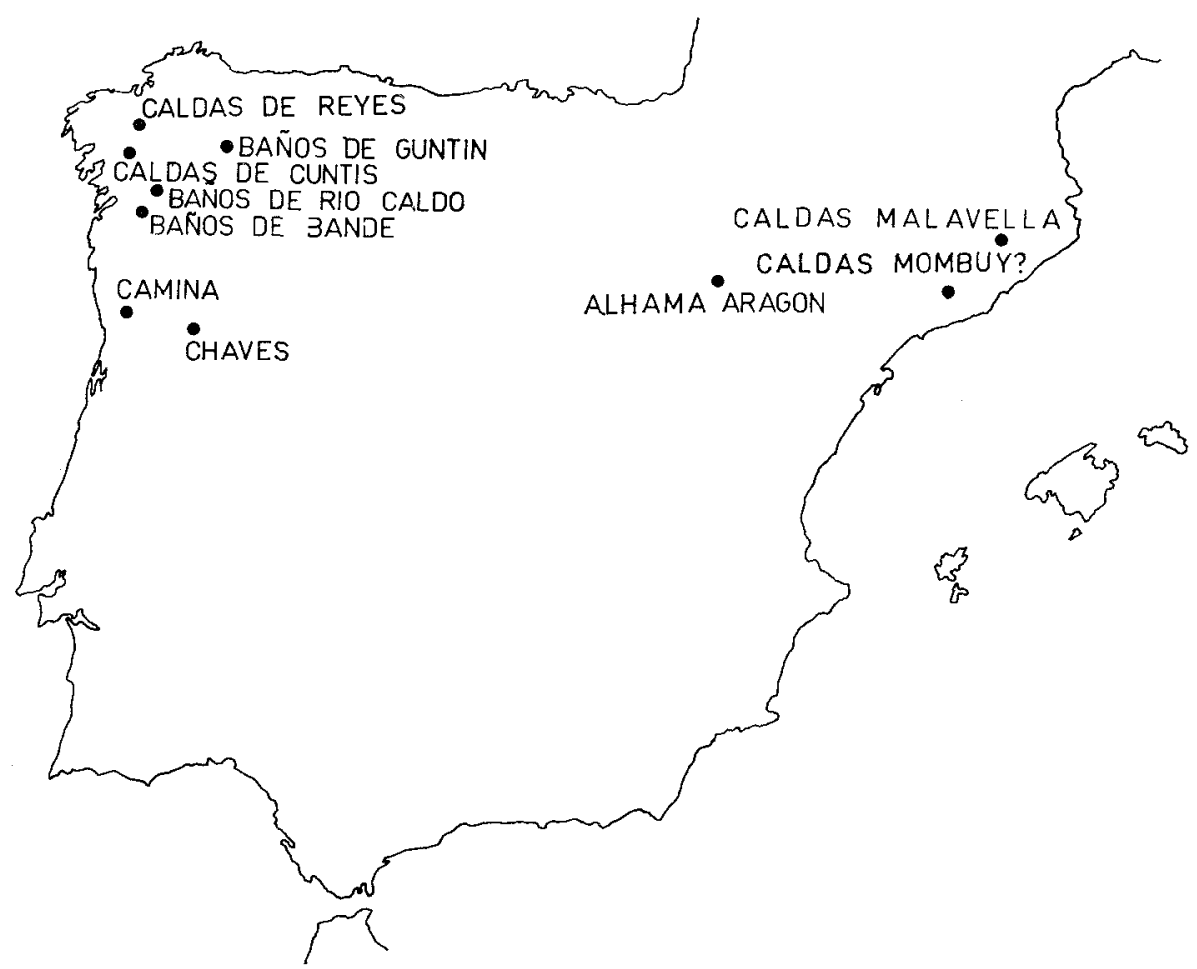

Lám. 1. Distribución de los lugares que llevan por nombre Aquae (según F. Diez de Velasco). 
Se han hallado en el balneario romano restos de fustes de columnas, de capiteles, y de basas. Las inscripciones recogidas están consagradas a las ninfas por Boelius, antropónimo indigena a Cari Beflacis ${ }^{25}$ y Diana.

\section{Baños de Guntin (Lugo)}

Es la antigua Aquae Quintiae del It. Ast (2) y de Ptolomeo $(2,6,27)$. En el balneario se halló un ara dedicada a Navia ${ }^{26}$.

Baños de rio Caldo (Orense)

Es probablemente la mansio Aquis Originis, mencionada en el ltinerarium Antonini $(428,1)$, en el Ravenate $($ IV,25), por el It. Ast. (4) y por el miliario de la calzada de Bracara Augusta a Asturica Augusta.

Hay restos de tejas, de ladrillos y de fábrica.

\section{Caldas de Cuntin (Pontevedra)}

Debe ser más bien Aquae Calidae que Aquis Celenis. Ha dado algún ladrillo romano y tégulas, más de 500 monedas romanas y una inscripción dedicada a las ninfas por C. Antonius Florus.

\section{Caldas de Malavella (Gerona)}

El balneario se alimenta de ocho fuentes de las que seis son termales, con una temperatura entre 50 y $60^{\circ}$. Se la identifica con Aquis Voconis del Itinierarium Antonini $(398,1)$. También las mencionan los Vasos Apolinares, el Ravenate (IV, 42; 5,3); Guidonis Geographica, 81 y la Tabla de Peutinger.

Una inscripción hallada en Caldas de Malavella menciona a un aqui caldense. Aquae Calidae están citadas igualmente en Plinio $(3,23)$ y en

${ }^{25}$ Blázquez, J. M., Religiones primitivas, 76, 150; ld., Diccionario, 520.

${ }^{25}$ Blazquez, J. M., Religiones primitivas, 178, 185, 195; ld., Diccionario, 131; Id., Primitivas religiones, 233,294 . Hoy día se cree que Navia es una diosa de los montes, de los bosques y de los valles selvosos, una Diana indigena (Bl.Azquez, J. M., Religiones en la España Antigua, 141). 
Ptolomeo $(2,6,69)$. El dedicante fue duoviri y edil, y pertenece a la misma familia citada en el ara consagrada a Apolo. De estos datos se desprende que las Aquae Calidae serían las Caldas de Malavella, y no Caldas de Montbuy.

Funcionaban dos balnearios alimentados por dos fuentes. En Puig de Les Animes, posible frigidarium, se descubrió una piscina regular, con dos escaleras de acceso, y orificio de entrada del agua. Del manantial E/s Bullidors se conocen galerías y una piscina (probable tepidarium). También se conservan galerias cubiertas por bóvedas de cañón, con aberturas en la división de ambas galerías y residuos de cañerías. Los restos de un arco posiblemente se relacionan con estas galerias. Hoy dia quedan tan sólo restos de una piscina con escalera de bajada con cinco peldaños, construida con sillares de granito, y una galería abovedada, que corria alrededor. También quedan tres habitaciones más pequeñas que serían posibles baños individuales. Se conservan restos de un acueducto de granito, y de un repartidor de agua de forma cúbica, y algunos conductos vecinos a las galerías. El plano general sería «una gran piscina alrededor de la cual había una serie de corredores con dos plantas, una situada a la altura de la piscina, y la superior encima de la primera» según Serra Ráfols. En Puig de Les Animes han aparecido monedas desde ases de Ampurias a bronces de Constantino, y en Els Bullidors 40 monedas.

Las inscripciones encontradas están dedicadas a Apolo, dios vinculado con las aguas en Caldas de Montbuy y en las Galias.

Caldas de Montbuy (Barcelona)

La temperatura del agua es de $70^{\circ}$. Se conocen en este balneario la existencia de una piscina con escalera de cinco gradas, una galería y varias salas abovedadas. Una inscripción de época Flavia está consagrada a Apolo por M. Fonteius Novatianus, cónsul. La segunda inscripción dedicada al mismo dios lo fue por L. Minucius Aponianus Tarraconensis, en época de Antonino Pio. La tercer dedicatoria a Apolo se debió a $L$. Vibius Alcinous. El dios lleva el epiteto de sancto. Cornelia Flora, de posible condición servil, dedicó un ara en honor de Minerva por la salud de Filipo. Salus contó con un ara levantada por $C$. Trocus Zoticus, se fecha esta inscripción en el siglo II. P. Licinius Philetus y Licinia liberta de Crasso costearon un ara a /sis. 
Caldas de Reyes (Pontevedra)

Posiblemente es la Aquis Celeris del Itinerarium Antonini $(430,3)$. La temperatura del agua oscilaba entre 30 y $46^{\circ}$. Próximo al balneario se han recogido monedas y un ara consagrada a Edovio ${ }^{27}$ por Amalus hijo de Clutius, ambos antropónimos indigenas. En la localidad también se halló un ara consagrada a Deo Mercurio por Fuscus, hijo de Fuscus.

Caminha (Miño)

Se ha supuesto que el lugar se pudo llamar en época romana Aquis Baenis o Aquae Minii, y en ella se ha localizado una de las dos Aquae Celenis del Itinerarium Antonini.

\section{Chaves (Vila Real)}

Se defiende que es la Aquae Flaviae; Aquae Laeae de Ptolomeo (2,6,39); Ad Aquas del Itineraium Antonini $(422,6)$ y del It. Ast. $(4,8)$.

Bajo el gobierno de los emperadores Flavios obtendría, a juzgar por el primer topónimo, el lus Latii. En esta localidad se han encontrado aras relacionadas con fuentes termales dedicadas a las ninfas (dos), a Tutela, a Isis, consagrada esta última por Cornelia Saturnina, a Apolo por el liberto M. lulius Tyranus Augustalis, que lleva su nombre de origen griego, y que es un servidor del emperador; Silvano contó con una posible dedicatoria que le costeó Camalus, antropónimo indígena que igualmente veneró a Bormanico en Caldas de Vizella.

\section{BALNEARIOS CON RESTOS EPIGRÁFICOS O ARQUEOLÓGICOS}

F. Díez de Velasco pasa a catalogar y a estudiar a continuación estos balnearios (lámina 2):

${ }^{27}$ Blázouez, J. M., Religiones primitivas, 175 ; Id., Diccionario, 93; Id., Primitivas religiones, 294. 


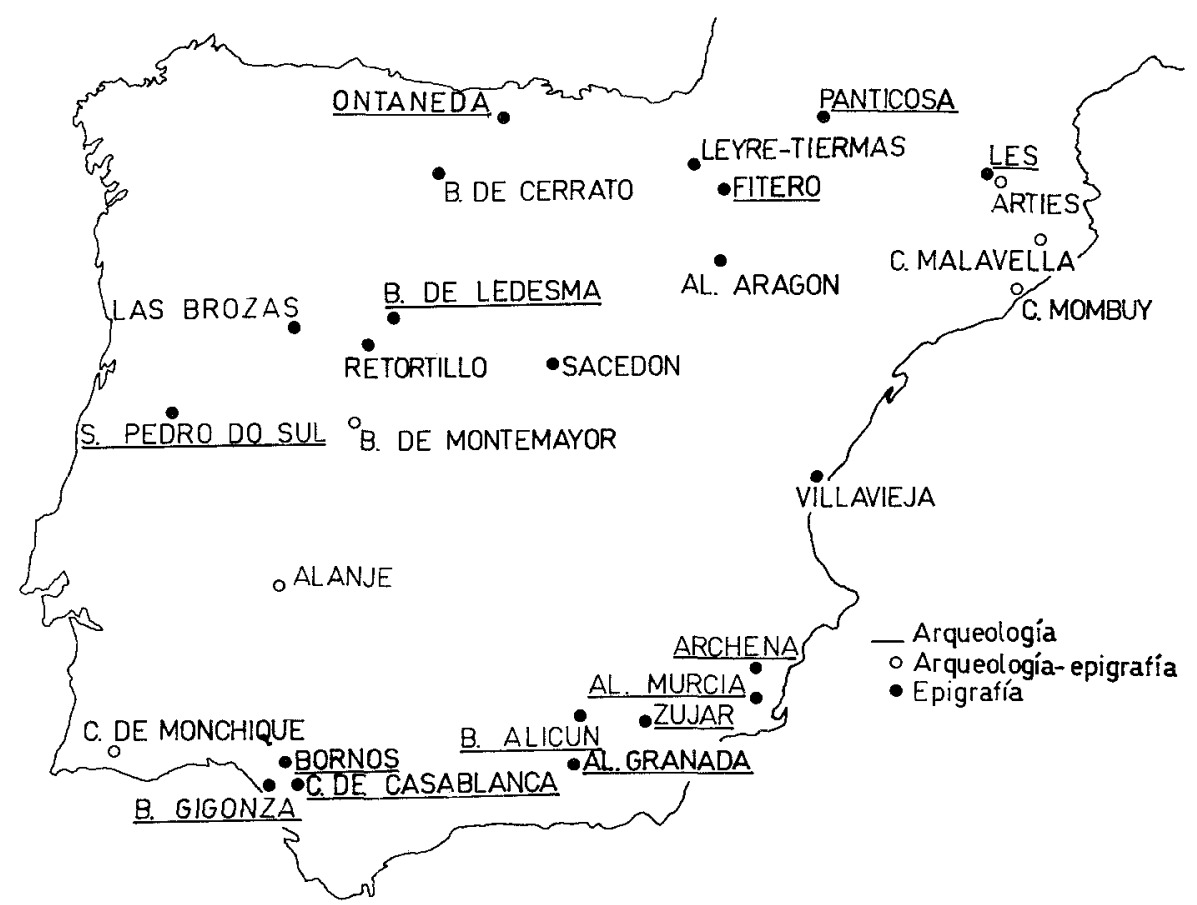

Lám. 2. Balnearios romanos, testimonios seguros (según F. Diez de Velasco).

Alange (Badajoz)

Es el Castrum Colubri de las crónicas medievales (El Silense Chron. Hisp. Lib. VIII, XXV - Chron. Hisp. Lib. IV, XXI). La temperatura del agua es de $26^{\circ}$ y su caudal de $316 \mathrm{l} / \mathrm{m}$. Se conserva aún hoy abierto al público el edificio romano. El balneario corista de dos salas; de escaleras de acceso; de puerta de entrada; de dos cámaras gemelas y de exedras abovedadas, de piscinas circulares con tres gradas concéntricas, de una cámara rectangular cubierta con bóveda de medio cañón con cornisa moldurada de nueve orificios circulares que serian respiraderos o enganches del velarum, y del oculus, o fuente de entrada de luz a las cámaras. Los elementos decorativos eran pinturas de temas florales y frutos, que cubrian las paredes, y posibles mosaicos en el suelo. Se supone que la canalización actual sigue la romana. Próxima al balneario se ha recogido un ara dedicada a luno Regina por Licinius Serenianus vir clarissimus y por Varinia Flaccina femina clarissima, por la salud de su hija Varinia 
Serena. El dedicante es personaje bien conocido. En tiempos de Maximino fue lagatus augusti propraetor en Capadocia. Cipriano $(E p .75,10)$ le recuerda como pagano ferviente. El padre de la espoca $C$. Varinius Fidus fue flamen. La fecha de la inscripción es la primera mitad del siglo III.

\section{Baños de Montemayor (Cáceres)}

Es el Caelionico o Caecilioni del Itinerarium Anionini $(434,1)$ con texto corrupto en los manuscritos, pero esta identificación no es segura. El agua alcanza una temperatura de $43^{\circ}$ y un caudal de $195 \mathrm{l} / \mathrm{m}$. El balneario dependería de Capara, que seria la ciudad vecina más importante. Se conservan la cámara circular abovedada con tres nichos circulares y la piscina en el centro, de forma cuadrangular y la fuente. Se han interpretado estos restos como el frigidarium. También se han recogido monedas arrojadas al agua como ofrendas.

Cuatro aras están dedicadas a las ninfas caparenses, varias a las ninfas, una a las ninfas de la fuentes, a Salus y a la fuente (?). En la actualidad se conservan once aras.

\section{Caldas de Monchique}

De este balneario se conservan varios restos arquitectónicos importantes: tanques de opus incertum revestidos de opus signinum; pavimentos de ladrillos; restos de canalizaciones y de construcción circular, quizás abovedada; piscina pavimentada en opus signinum; edificación cuadrada con pequeña piscina pavimentada en opus signinum; edificación incompleta con piscina rectangular pavimentada con opus signinum, restos de muros y de pared que delimita el edificio balnear. Un ara está consagrada por Patuleia a las aguas sagradas. Partes del balneario estaban decoradas con mosaicos. Entre los objetos de metal probablemente ofrecidos a las aguas cabe recordar una palmeta de oro, 115 alfileres de plata y objetos de hierro, una joya, y varias monedas fechadas entre los emperadores Augusto y Arcadio, fecha en que el baineario se encontraba abierto al público.

\section{Caldas de Vizella (Oporto)}

El balneario tenía diez u once piscinas. También apareció otro baño y algunos compartimentos abovedados, y mosaicos con decoración entrelazada y cruciforme. 
Las inscripciones encontradas están consagradas a Bormánico, una por Medamus Camalus, indigena a juzgar por el nombre, y una inscripción dedicada a un gran número de dioses: luno Regina, a Minerva, al Sol, a la Luna, a Fortuna, a Mercurio, a los genios de lupiter y de Marte, a Esculapio, a Venus, a Cupido, etc. En las proximidades de Caldas de Vizella se han recogido una inscripción a las ninfas lupianas dedicada por Antonia Rufina en Tagilde, y una segunda sólo a las ninfas en Guimaraes. F. Díez de Velasco ha catalogado los topónimos relacionados con la raíz del dios termal Bormanico, que se relacionarían con balnearios: Bormate y Bormas en Albacete; Rio Borma en León; Bormujos en Sevilla; Gormaz en Soria; Bormos en Cádiz con aguas termales a! igual que Río Borma; Bormen en Pontevedra y Bormella en las proximidades de Caldas de Vizella.

Lucus Augusti (Lugo)

Esta ciudad está bien documentada en las fuentes literarias antiguas (Plin. 3,28; It. Ant. 429,7; 430,8; It. Ast. 2; Rav. IV, 45; Ptol. 2,6,23). En el actual balneario de Lugo, cuyas aguas salen a $45^{\circ}$ de temperatura, se han descubierto restos de cámaras romanas, cuadradas y abovedadas, con hornacinas en las paredes formando un arco de medio punto. Hay otras dos cámaras abovedadas con aparejo de pizarra. Una Inscripción está dedicada a Laho Paraliomego ${ }^{28}$ por Caelius Rufinus. Otras inscripciones de Lugo, que se han relacionado con las aguas, algunas sin mucho fundamento, lo están a Tutela, a Verore ${ }^{29}$, Virrore o Veroce, a Caelesti, a Reus Paramaeco ${ }^{30}$ (lámina 3).

\section{BALNEARIOS CON RESTOS ARQUEOLÓGICOS Y EPIGRÁFICOS SUFICIENTES}

Valle de Arán (Lérida)

En este valle se construyeron dos balnearios romanos en Arties y Les respectivamente.

\footnotetext{
${ }^{28}$ Blazquez, J. M., Primitivas religiones, 301, 304, 484.

${ }^{29}$ Blazquez, J. M., Primitivas religiones, 228; Id., Diccionario, 182.

${ }^{30}$ Blazzouez, J. M., Primitivas religiones, 139; Id., Diccionario, 137; Id., Primitivas religiones, 484.
} 


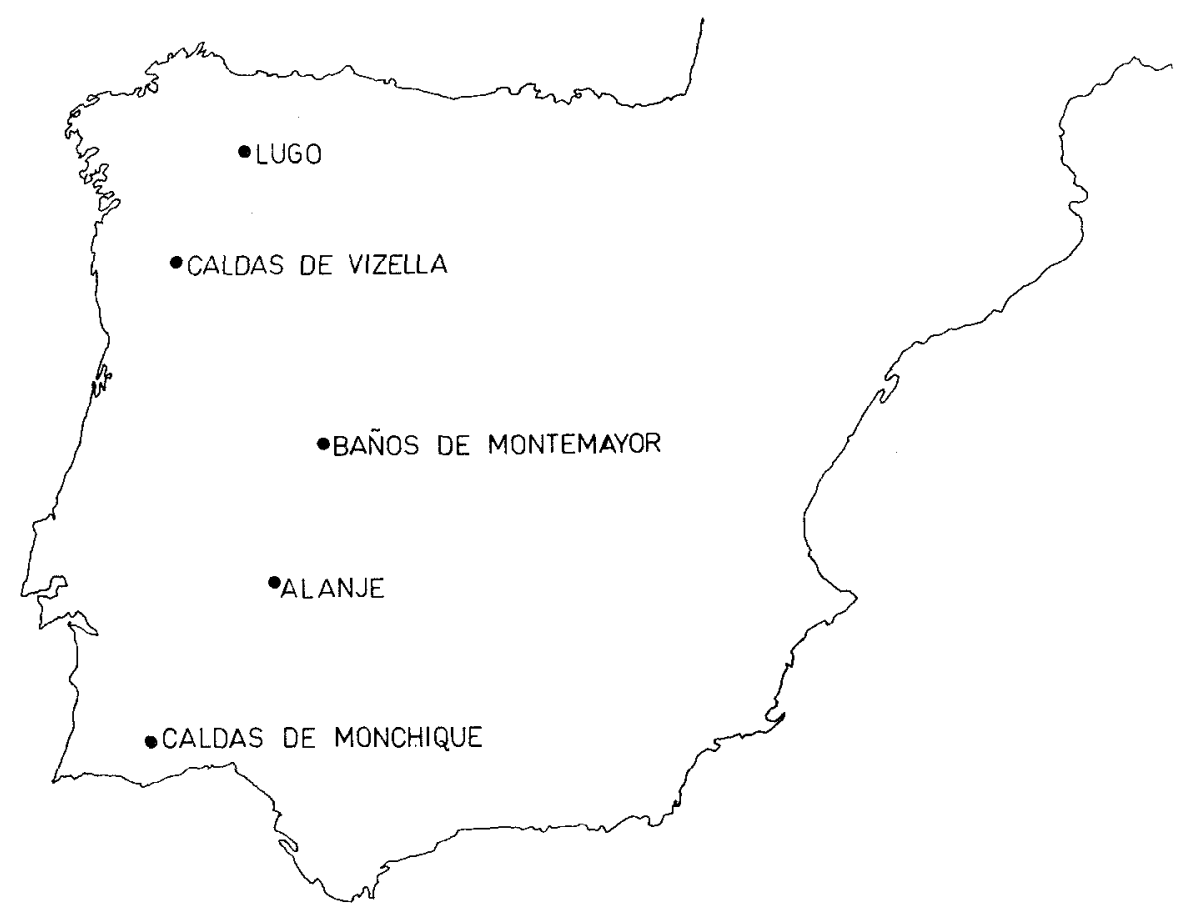

Lám. 3. Balnearios con restos de importancia (según F. Díez de Velasco).

En la primera población los restos arqueológicos son poco importantes. Entre ellos destaca una inscripción a las ninfas. En el balneario moderno de Les se descubrieron tejas, ánforas romanas, monedas romanas y restos arqueológicos.

Archena (Murcia)

En el siglo xix aún existían restos de las termas romanas, y trozos de galerías que ocultaban las bóvedas. Una inscripción conmemora la reconstrucción de las termas medicinales dedicada a $D$. Cornelius Carito, a L. Heius Labeo, que eran dunviros, aquas ex decreto decurionum reficiendas curarunt. En una segunda inscripción, también encontrada en el balneario, se alude a una probable reconstrucción costeada por L. Turcilius Rufus. 
Baños de Cerrato (Palencia)

La temperatura del agua es de $52^{\circ}$ y su caudal $2.400 \mathrm{l} / \mathrm{m}$. Un epígrafe dedicado a las ninfas indica la existencia de un balneario.

Baños de Ledesma (Salamanca)

El balneario romano, con aguas de $48^{\circ}$, está enmascarado probablemente en el actual. El agua brota de una piscina central.

Baños de Molgas (Orense)

Tradicionalmente se los identifica con Aquae Geminae, pero ello no es seguro. Alrededor de las aguas medicinales termales se han descubierto, al parecer, restos de termas romanas: tejas, ladrillos, restos de canalización de agua, de infraestructura arquitectónica, monedas y dos inscripciones consagradas a las ninfas.

\section{Baños de Zújar (Granada)}

Se conservan los restos de los mosaicos del caldarium. Seis cámaras, al parecer, son romanas, abovedadas al igual que dos arcos. En las proximidades hay una piscina pequeña de hormigón romano. Entre esta piscina y la parte posterior del balneario moderno se detectan posibles restos de canalización, que conducen el agua al actual manantial desde la primitiva fuente. Romanas son las gradas en las pequeñas habitaciones.

Bem-Saude (Bragança)

En esta localidad hay una fuente termal, hoy ya abandonada. Se encontró una inscripción dedicada a las ninfas.

\section{La Calda (León)}

El río se llamaba antiguamente Borma, nombre relacionado con el teónimo Bormanico. En las proximidades del rio brota el manantial de La 
Calda. El nombre del pueblo Boñar se menciona en 952 como Balneare, nombre bien latino. Una inscripción está consagrada a Fontis agineesis genio por un Aquilegus de la Legio VII Geminae.

\section{Bormos (Cádiz)}

El nombre del pueblo actual se relaciona con el teónimo Bormanico. En esta localidad han aparecido dos esculturas de ninfas, desnudas y recostadas, fechadas en el siglo II.

\section{Caldas de Canaveses (Oporto)}

Se conoce la existencia de un balneario romano del que se conservan tejas, fragmentos de cemento de piscinas romanas y mosaicos de opus signinum.

Caldas de Lafoes (Portugal)

Al balneario romano pertenecian restos de $\operatorname{arcos}$ y un baño con escalera de descenso, un segundo baño de mujeres, con escalera y otros baños vecinos de menor tamaño.

Los baños mixtos los prohibió Adriano, pero esta prohibición no se debió cumplir. La Iglesia tuvo una postura ambigua ante los baños. En la Didascalia o Doctrina Católica de los doce Apóstoles, posible obra siria de la primera mitad del siglo III, se alude (2) a la promiscuidad en los baños. Cipriano en su tratado De habitu virginum prohibe a las virgenes cristianas frecuentar los baños mixtos. Este tratado es posterior al año 249 fecha de la consagración episcopal del autor. Se acusaba a la secta de Tertuliano de abstenerse del baño en los días penitenciales (de eiiunio adversus psychicos, 1). Atanasio, en un tratado sobre la virginidad, exhorta a las virgenes a abstenerse de los baños. Opinión contraria sobre el uso de los baños es la del obispo de Footide en Epiro, Diadoco, uno de los grandes ascetas del siglo $v$, quién en su obra Cien capitulos sobre la perfección espiritual, que es un manual de ascetismo, en el capitulo 52, afirma que nadie tiene obligación de abstenerse del baño, que es refrescante.

Se conocen dos aras procedentes de este balneario. Una de ellas está consagrada a Mercurio Augusto Agnaeco por Pelagius Reburrus, hijo de 
Recientes aportaciones al culto de las aguas en la Hispania romana

Reburri y por Victoria Victorila mater. Se conserva en esta inscripción una mezcla de nombres indigenas y romanos, que indican bien que todo tipo de devotos, gentes plenamente romanizadas e indigenas frecuentaban estos baños medicinales.

Caldelas (Braga)

En las paredes del balneario romano se hallaron empotradas dos aras dedicadas a las ninfas. El topónimo alude a la existencia del balneario romano.

Fitero (Navarra)

En esta ciudad navarra existió un balneario romano. El edificio de la toma de aguas moderno es de época romana según indica su silleria. Posiblemente es también romana una piscina aún en uso hoy.

\section{Guitiriz (Lugo)}

Se ha relacionado con este balneario, cuyas aguas salen a $15^{\circ}$, con un caudal de $28,3 \mathrm{l} / \mathrm{m}$, la inscripción de las cercanías de Os Curveiros, municipio de Transparga, consagrada a Cohvetene, diosa que aparece en Procolitia en el Muro de Adriano en Britania, que seria el numen que habitaba en la fuente salutifera del lugar.

Es una diosa no autóctona, y cuyo culto no fue importando por ningún soldado de la Legio VII Gemina, tenía un carácter profético, como lo indica el último renglón: ex responso numinis. Se ha supuesto también que sería una diosa que presidia las reuniones comerciales interpretando la última línea $e(x) r(e d i c t u) ~ n(u m m o r u m)$, teoría que $F$. Diez de Velasco juzga menos aceptable. La aparición de una segunda ara induce a este autor a pensar que «hace más difícil aceptar que se trate únicamente de una diosa tópico-termal y debemos pensar de ella como diosa de las aguas salutiferas en general sin ninguna localización topográfica obligada».

\section{Ontaneda (Cantabria)}

En el balneario moderno se recogieron monedas desde Augusto a Constancio II, que indican ofrendas a las aguas. 
Orense

En el balneario de las Burgas de Orense se recogió una lápida consagrada a las ninfas dedicada por Abana, antropónimo con la raíz $a b=$ agua.

\section{Panticosa}

De este balneario, cuyas aguas tienen una temperatura que oscila entre los 40 y $51^{\circ}$ con un caudal de $185 \mathrm{l} / \mathrm{m}$, se conservan restos de la captación romana; estaba abierto al público en época de Augusto, como lo indica una moneda de Caesaraugusta. Otras monedas halladas son de Sagunto, en latín y un as de Celsa de tiempos de Tiberio.

Retortillo (Salamanca)

La temperatura del agua de este balneario es de $46,5^{\circ}$ y su caudal de $212 \mathrm{l} / \mathrm{m}$. Al balneario romano pertenece la obra de piedra de sillería, el pozo artificial, ladrillos, baldosas y cerámica romana fina, un fíbula de bronce, una veintena de monedas romanas y seis aureos.

Un ara está dedicada por Eaccus, hijo de Albino, a las Aquis Eletesibus, cumpliendo un voto, lo que indica que se hacían votos impetrando de las aguas la curación. El nombre del dedicante es indigena y de origen celta.

San Vicente do Pinheiro (Oporto)

En época romana estaba en funcionamiento un balneario de aguas sulfurosas, fechado en el siglo III. Se demostró en la excavación efectuada la existencia del apodycterium, del tepidarium, del caldarium, y del irigidarium.

\section{Tiermas (Zaragoza)}

El topónimo actual deriva del latino thermae. Al balneario romano pertenecen vestigios de la fachada, aposento pavimentado con mosaico, restos de piscina circular. Se recogieron numerosas monedas y un ara con- 
Recientes aportaciones al culto de las aguas en la Hispania romana

sagrada a las ninfas por Quintus Lucinius Uscus Aquilegus Varaiensis (Vana o Varea). El oficio de aquilex, citado igualmente en un ara de Legio VIII Gemina consistía en detectar aguas subterráneas.

Tremañes (Gijón)

Se conoce la existencia de unos baños de argamasa y de un ara dedicada a la Fortuna Balnearis por T. Pompeius Peregrinianus, para obtener de la diosa la salud suya y de los suyos. Esta última frase indica bien a las claras, que los devotos buscaban en los balnearios la salud corporal, y que eran balnearios salutíferos, no higiénicos. Se ha interpretado los restos arqueológicos hallados como pertenecientes a una villa. F. Díez de Velasco es de la opinión que todos los hallazgos son de un mismo conjunto: unas termas medicinales probablemente (lámina 4).

\section{BALNEARIOS DOCUMENTADOS DE MODO ESCASO}

Alhama de Granada

El manantial tiene un caudal de $4.850 \mathrm{l} / \mathrm{m}$, y una temperatura de 47 $49^{\circ}$. Hay noticias de ruinas de unas termas.

Alhama de Murcia

Se conservan vestigios de baños de aguas medicinales, con cisterna abovedadas.

Baños de Alicún de las Torres (Granada)

La temperatura de las aguas es de $34^{\circ}$ y el caudal de $350 \mathrm{I} / \mathrm{m}$. Junto al balneario actual hay restos de población romana. Las aguas se utilizaron desde la prehistoria. 


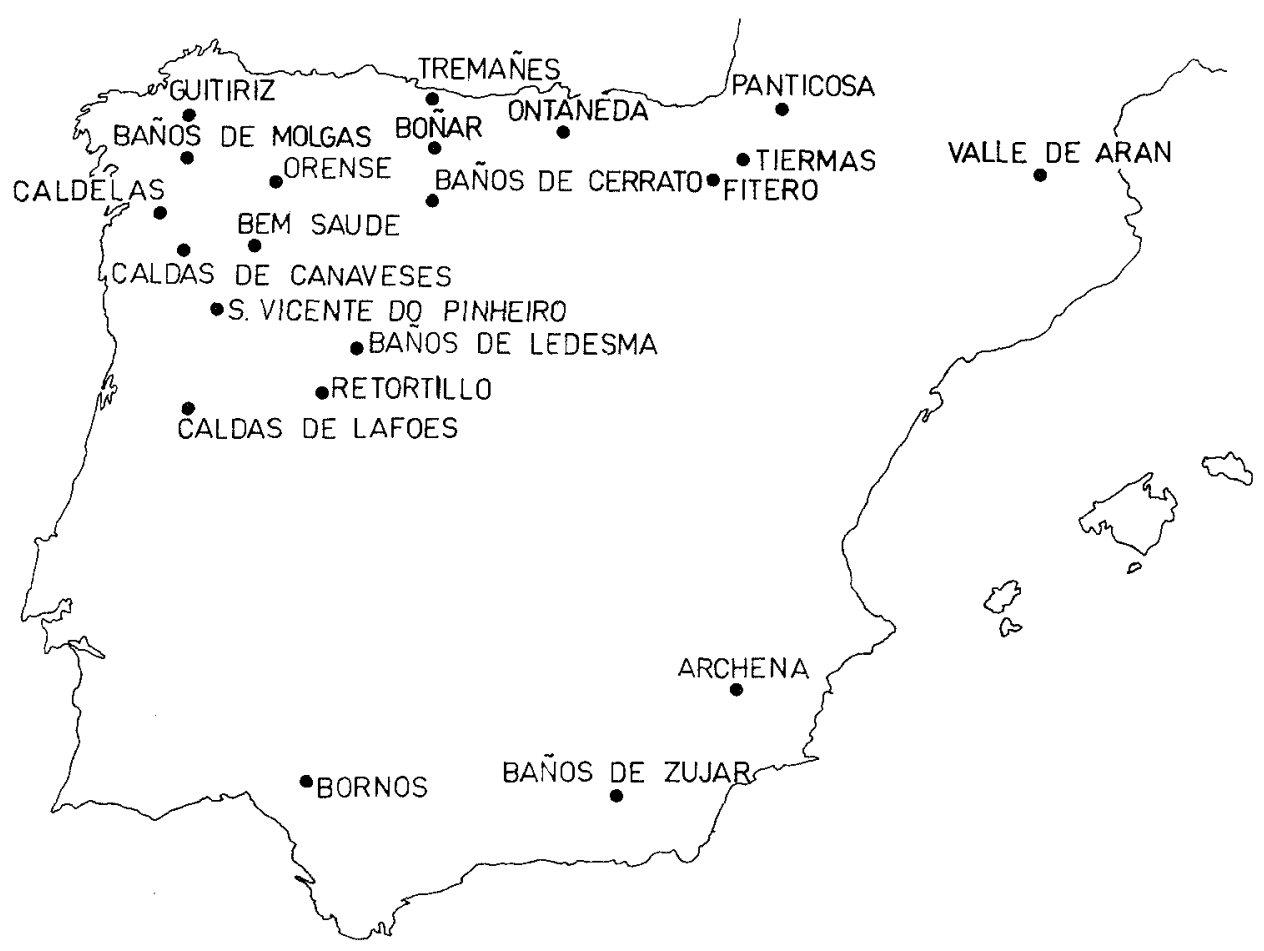

Lám. 4. Balnearios testificados de modo suficiente (según F. Díez de Velasco).

Baños de Béjar (Salamanca)

Se conserva una sala con sus nichos.

Baños de Gigonza (Cádiz)

En este lugar se sitúa la antigua Saguntia de Livio $(34,19)$, de Plinio $(3,15)$, de Ptolomeo $(2,4,10)$ y del Ravenate $(I V, 5)$. Se ha supuesto que la ciudad se formó en torno a la fuente termal.

Baños de Graena (Granada)

Las aguas brotan a una temperatura de $44^{\circ}$. Próximos al balneario moderno han aparecido lucernas, tejas, un capitel y cerámica, que prueban la existencia de una población romana que debió utilizar el manantial. 
Recientes aportaciones al culto de las aguas en la Hispania romana

Caldas de Taipas (Braga)

En las cercanías de esta localidad se halló un ara consagrada a las ninfas por G. Sulpicius Festus, en cumplimiento de un voto, fechada después del siglo II. El topónimo actual alude a la existencia de un balneario.

Caldas de Velhas de S. Lorenzo

Hay posibles restos de un balneario, de aguas sulfúricas que desaguan en una piscina cubierta.

Caldas de Monte Real

Se cree que existió aquí un balneario abierto en los siglos II y III. Se recogió en la localidad un ara dedicada a Fortuna o Fontana. El topónimo actual alude a la existencia de un balneario.

Carballo (La Coruña)

Las aguas, con un caudal medio de $80 \mathrm{l} / \mathrm{m}$, tienen una temperatura de $23-35,7^{\circ}$. Se conoce de este lugar una fuente subterránea abovedada con escalera posiblemente de época romana.

Cortijo de Casablanca (Cádiz)

Se ha localizado aquí la antigua Lacca levantada alrededor de una fuente termal.

Duratón (Segovia)

Se halló en Duratón una inscripción relacionada con las termas salutíferas romanas, dedicada a la Fortuna Balnearis, diosa que aparece en Tremañes, por Q. Valerius Tucco miles legionis /I Adiutrix y por Aemilius Secundius. 
Mondariz (Pontevedra)

Sus aguas alcanzan una temperatura de 13 a $16,4^{\circ}$. Aparecieron restos de pilas y de cañerías antiguas. En las proximidades existen topónimos relacionados con la raíz céltica bherw = borbotear, como el río Borbén, el descampado de Borbén con restos romanos y la mansio Burbida (It. Ant. $430,1)$, o la Bonisana del Ravenate (IV,43-307,18).

Santa Cruz de Loyo (Orense)

En esta localidad se halló un ara consagrada a Cuhve(tene) Berralogecu por Flavius Valerianus, en cumplimiento de un voto. El epiteto que acompaña a la diosa es de tipo geográfico. El antropónimo del dedicante es flavio.

Tijola (Almeria)

La temperatura de las aguas termales es de $27^{\circ}$. Un pedestal está dedicado a las ninfas por L. F. Argyrinus. Una inscripción monumental costeada por Voconia Avita conmemora la construcción de las termas de la República Tagilitana y de otros gastos suntuarios. Se desconoce si estas termas son de aguas medicinales o simplemente higiénicas.

Valencia de Alcántara (Cáceres)

Una inscripción hallada en una finca de esta población está consagrada a Salus, y una segunda por Valeria a Apolo. Existen una captación de aguas y una conducción.

Villavieja (Valencia)

Las aguas termales tienen una temperatura de $45-48^{\circ}$. Se ha pensado que debió existir aquí un balneario. 


\section{LA PÁTERA DE OTAÑES Y LAS FUENTES TAMARICAS}

En el pico del Castillo en el valle de Otañes en las proximidades de Castro Urdiales (Santander), se halló una pátera de plata en la que se describe gráficamente la utilización de las aguas con propiedades curativas.

La inscripción reza Salus Umeritana y en el reverso L. P. Corneliani. En el anverso se representa a Salus en la zona superior, bajo la forma de mujer recostada en el suelo con una rama en la mano derecha y un recipiente del que brota agua, que cae en un depósito fabricado con piedra, precedido de un puente. Flaquean a Salus dos árboles. A la izquierda un varón togado y barbudo hace una ofrenda de líquido sobre un altar.

A la derecha un segundo hombre barbado y encorvado, ofrece un sacrificio sobre un altar, posiblemente se trata de un enfermo. Más abajo un varón anciano y barbado, sentado en un sillón, se dispone a beber agua medicinal que le ofrece un esclavo.

Otras dos escenas representan el envasado del agua. En la central un esclavo se dispone a tomar el agua de la fuente, lo que prueba que el agua salutífera se llevaba a los enfermos. En la parte inferior otro esclavo Ilena un tonel de agua colocado encima de un carro, tirado por bueyes, mediante un ánfora.

El adjetivo Umeritana alude a la diosa que habitaba en la cima y que protege con sus aguas a los habitantes de la comarca.

L. P. Corneliani sería el nombre, probablemente del platero que fabricó la pieza, o del dedicante, enfermo que se curó mediante la bebida del agua... La pátera se fecha en época flavia.

\section{Velilla del Grado}

Se situaan en este paraje las Fontes Tamarici de Plinio (31,23-24). No se han descubierto, hasta el momento presente, minas romanas. El texto de Plinio dice: «y en Cantabria las Fuentes Tamaricas sirven para obtener augurios; son tres, distantes entre si ocho pies; se juntan en un solo lecho formando un gran caudal. Están en seco durante doce dias, y a veces hasta veinte, sin que se pueda ver agua alguna, mientras una fuente contigua conserva sin interrupción un gran caudal. Cuando los que las quieren ver las encuentran secas, ello significa un presagio funesto, como sucedió recientemente a Lartius Licinius, legado propretor, que murió 
después de siete dias». Plinio informa en este párrafo de una faceta desconocida hasta ahora de los manantiales, que de ellos se obtenían presagios.

Durante su estancia en Hispania, con ocasión de las Guerras Cántabras (29-19 a. C.), Augusto se curó de una enfermedad bañándose en un cubo lleno de agua termal, a esta curación alude Crinagora, poeta griego contemporáneo de Augusto, y Suetonio (Aug. 81-82). El poeta menciona un balneario; Suetonio puntualiza que la enfermedad, que padecía el emperador, era del higado. Su médico Antonio Musa, le recomendó tomar agua fría. El baño consistía en tener alternativamente las manos y los pies en un caldero llamado en lengua indígena hispana dureta. Los baños eran sulfurosos calientes.

El balneario estaria localizado en Hispania y no en Dax como piensa A. Schulten.

\section{TESTIMONIOS POCO SEGUROS O HIPOTÉTICOS DE BALNEARIOS}

F. Diez de Velasco termina su importante trabajo con un catálogo de estos balnearios de época romana. Estos son: Araya (Álava) con inscripción a las ninfas; Arciniega (Álava) con inscripción a Sandao Vimumburu ${ }^{31}$, dios de tipo fluvial; Bencatel (Portugal), con ara dedicada a Fontano y Fontana para obtener la salud de Albio Fausto por Albia Pacina; Bóveda (Orense), con lápida dedicada a las Ninfas Salutares por Sulpicia Saturnina, se fecha en el siglo ॥; Las Brozas (Cáceres), con ara consagrada a Bandiaeapolosegolu ${ }^{32}$, dios de carácter termal por Lupus Flaus; Burguillos (Badajoz), con inscripciones en honor de Fontana por Flavia Severa, y de Diana por Q. Antonius Crescens Severianus, una tercera inscripción menciona el cargo de curatir balinei en relación con la construcción de termas; Cabriana (Álava), una dedicatoria a Uvarna ${ }^{33}$, diosa de carácter acuático, y otras dos inscripciones a las ninfas; Campillo de Arenas (Jaén), con dedicatorias de unos libertos en honor de Salus; Castro Caldelas (Orense), con inscripción a Nabia Elaesurraecae; Cortijo del Ahorcado (Jaén), con fuente termal en la zona; Curbian (Lugo), con dedicatoria a Bandue Bolecco por Sulpicius Sincerus, dios de posible carácter acuático; Escaña, con dos inscripciones a Apolo y a Esculapio, ambos dioses frecuentemente relacionados con las aguas, y a Fons Di-

${ }^{3}$ Blazquez, J. M., Diccionario, 146; Id., Primitivas religiones, 485.

${ }^{32}$ Blázquez, J. M., Religiones primitivas, 52; /d., Primitivas religiones, 296.

${ }^{33}$ BıÁzquez, J. M. Primitivas religiones, 486. 
vina, la primera por Postumius Castrensis y la segunda por L Postumius Satullus; Feria, con inscripción a Fontana; Forua (Vizcaya), con dedicatoria a luiliae ${ }^{34}$, diosa de probable carácter acuático, por $M$. Caecilius Montanus, por la salud de Fusco, su hijo, que confirma que se hacian votos por la salud de otras personas a los dioses acuáticos; Lancia (León) con inscripción a Apolo; Legio VII Gemina con inscripciones a las ninfas de la Fons Amevi por Cn. L. Terentius Homullus, iunior, legado de la legión; tres a ninfas, una de ellas erigida por $T$. Pomponius proculus Vitrasius Pollio, que desempeñó los cargos de cónsul, pontifex, procónsul, legado de Augusto, propretor de la provincia de Moesia Inferior y de Hispania Citerior, y por Faustina. Se fecha en época de los Antoninos. Prueba esta dedicatoria que el culto a las aguas termales encontraba devotos entre las supremas magistraturas del Imperio. Su esposa dedicó otra inscripción en Aquae Griseliae, a las ninfas grisélicas. La tercera inscripción de las ninfas lo fue por $Q$. Cornelius Anteros, que era imaginifer de la legión. Se fecha en el siglo II. Una última inscripción está consagrada a Esculapio, Serapis e Isis por L. Cassius Paullus Augustanius Alpinus Bellicus Sollers y por $M$. Cassius Agrippa Sactus Paullinus Augustanius Alpinus, que pertenecen a la gens cassia y eran de familia senatorial.

Otros balnearios hipotéticos catalogados por F. Díez de Velasco son: Linares (Segovia); La Mala (Granada); Montanchez (Cáceres), con inscripción erigida por el indígena Caturo a la Salus Bidiensis; Quintanilla de Somuño (Burgos), con dedicatoria a las ninfas por el indígena Paesica; El Rasillo de Cameros (La Rioja), con inscripción a Caldo Uledico, dios de carácter acuático; Santa María de Aguas Santas (Orense), que es posible la mansio Salientibus del Itineraium Antonini, 428,4, y del Ravenate IV,45; Sacedón (Cuenca), con termas; Senhora da Luz (Faro), con termas higiénicas; Talavera de la Reina (Toledo), con inscripción a las ninfas; Tejares (Salamanca), con posible fuente medicinal; Torreblanca del Sol (Málaga), con establecimiento termal de posibles aguas curativas, y escultura de varón personificación de una fuente; Tricio (La Rioja), con inscripción a las ninfas, cañerías y monedas en la zona; Ubrique (Granada), con posibles termas; Uclés (Cuenca), con inscripción a Deo Airon, dios de carácter acuático, dedicado por la familia oculesis (Uclés), con depósito del que brota el agua a borbotones; Valtierra (Navarra), con inscripción a las ninfas Varcilenis debida a L. I. Rufinus; Villavermudo (Palencia), con inscripción a las ninfas y mosaico de Diana; Villasbuenas (Salamanca), con inscripción dedicada a Celiborca, diosa de posible carácter acuático. Otras

\footnotetext{
${ }^{34}$ Blázquez, J. M., Religiones primitivas, 198; Id., Diccionario, 109; Id., Primitivas religio-
} nes, 481 . 
inscripciones ha dado Hispania consagradas a las ninfas, a las fuentes, a Salus, que resultan más dudosas que los testimonios anteriores, que se relacionan con balnearios medicinales.

M. Dupré y M. J. Peréx Agorreta ${ }^{35}$ han estudiado el termalismo y religión en el norte de Hispania (Desde los Pirineos al Ebro). Señalan ambas autoras que toda la zona, de Galicia a Cataluña es rica en aguas minero-medicinales. En el ángulo noroeste hispano predominó el culto a las fuentes asociado al de los dioses indigenas, debido al carácter céltico de la región, y a su menor romanización; mientras en el noreste se documentan principalmente establecimientos termales, las más veces urbanos, y colocados bajo la protección de los dioses del panteón clásico, debido a la intensidad de la romanización. Estudian ambas autoras la zona comprendida entre los Pirineos y el Valle del Ebro, subdividida en dos regiones: la montaña y los valles y mesetas, con mezcla de diferentes pueblos (celtas, iberos, vascones), reagrupados en el conventus caesaraugustanus.

N. Dupré y M. J. Peréx Agorreta estudian el tipo y la distribución geográfica de los establecimientos termales conocidos por la arqueología y la epigrafía, el origen y el grado de romanización de los dedicantes, el nombre y la naturaleza de los dioses, vinculados con las aguas curativas. Salvo dos fuentes referentes a Tarragona y a San Martin de Trevejo (Cáceres), la lista de los dioses de carácter acuático pertenecen a siete provincias españolas, de las que sólo en cuatro casos (La Rioja, Navarra, Huesca y Zaragoza) corresponden a una realidad antigua, que en parte siguen las divisiones étnicas prerromanas. Doce inscripciones dedicadas a dioses de carácter acuático se encuentran en este cuadro geográfico, de las que dos quedan fuera pero pertenecen al eje establecido por el Ebro. Una es una base de estatua del Ebro, aparecida en Tarraco, capital de la provincia. La segunda se halló en Lusitania y está dedicada al Deo Salamati ${ }^{36}$, de probable carácter acuático por su epíteto Nabia. El antropónimo Ibero sería la manifestación de un culto a este río como en el caso del Durius de una inscripción de Oporto (C.I.L. II, 5279).

Se plantean estas dos autoras la razón de hallarse una inscripción dedicada al Ebro, tan lejos de este río. No descartan que el hidrónimo Ebro pueda aplicarse a cualquier río, opinión que encontramos muy acep-

\footnotetext{
${ }_{35}$ "Thermalisme et religion dans le nord de l'Hispania (des Pyrenées à l'Ebre)", (Aix-lesBains, 1990). Tours 1992, págs. 151-169.

${ }^{36}$ Blazquez, J. M., Religiones primitivas, 188; Id., Diccionario, 146; Id., Primitivas religiones, 195; Id., Religiones primitivas de Hispania, 142.
} 
tada, y que explicaría satisfactoriamente la afirmación de Apiano (Iber. 10) de que Sagunto está situado encima del Ebro.

De las diez inscripciones, cuatro pertenecen a la actual provincia de Álava, de las que tres han sido encontradas próximas al Ebro. En Cabriana, en un posible edificio termal, otra procede de Araya, donde nace el río Ciraunza.

Tres inscripciones se han recogido en Navarra: la de Valtierra yacía junto a una fuente medicinal. La de Leire es posible que proceda del establecimiento termal de Tiermas. La citada inscripción de Alhama de Aragón se vincula con unas termas medicinales. Las dedicatorias de Rasillo de Cameros y de Nuestra Señora de los Arcos, localidad próxima a Tricio, no se relacionan con aguas medicinales. Siete inscripciones están en función de fuentes, de corrientes de aguas o de balnearios medicinales. De entre los cuatro establecimientos antiguos documentados, los mejores conocidos son los que han proporcionado juntamente restos arqueológicos e inscripciones.

Ya se ha aludido a los balnearios de Alhama de Aragón, de aguas sulfatadas, con su inscripción dedicada a la Tutel(ae) genio loci ${ }^{37}$; al de Fitero con sus catorce baños, con su canalización que conducía al castellum aquae, fechado a final del siglo 1 o a comienzos del siguiente; y al de Panticosa. En tres lugares del norte de Hispania asociados al termalismo o a el culto a las aguas se conservan ruinas (Tiermas, Fitero, Panticosa); uno se conoce gracias a los datos conjuntos de la arqueologia y de la epigrafía (Alhama de Aragón), y de siete se conservan inscripciones votivas en relación con el culto a las aguas. N. Dupré y J. M. Peréx Agorreta comparan estos documentos con los teónimos aparecidos. Llama la atención la repartición irregular de las dedicatorias y la ausencia en las regiones orientales. Ni Lérida ni Teruel han suministrado inscripciones del culto a las aguas o del termalismo, quizás debido a la ausencia de piedra. Las termas se han documentado en el interior del Conventus Caesaraugustanus, en relación con una ciudad (Aquae Bilbilitanorum), y quizá Turiaso y Alfaro, o en una localidad de tipo indigena (Fitero, Tiermas). En ambos casos la estructura del edificio es romano y se encuentran en ellas una inscripción dedicada a los dioses sanadores: Deo Tutelae genio loci en Alhama de Aragón y Nymphis en Leyre. El santuario de Panticosa está levantado en un alto, como ciertos santuarios de Aquitania. Navarra no ha dado ninguna inscripción dedicada a los dioses acuáticos.

${ }^{37}$ Blázquez, J. M., Religiones primitivas, 51, 57, 225; Id., Primitivas religiones, 262, 296, $305,308$. 
Las tres dedicatorias a las Nymphae (Valtierra y Leyre) y a Lacubegi ${ }^{38}$, cuya procedencia exacta se desconoce, se han hallado en lugares próximos a la provincia de Zaragoza, y no balnearios (22 inscripciones votivas conocidas entre el Ebro y Pompaelo). La Rioja sólo ha suministrado dos dedicatorias a los dioses acuáticos, a las Nymphae en Tricio y a Caldo Uledico en Rasillo de Cameros, entre 20 inscripciones votivas en territorio berón.

El territorio de los várdulos, autrigones y caristios, que pertenecían a! Conventus Cluniensis, ha dado 20 inscripciones votivas, de las que un tercio son de dioses de carácter acuático (uno en Araya y cuatro en Cabriana).

El número de inscripciones votivas de Navarra, La Rioja y Álava, contrasta con la ausencia de ellas en las provincias limitrofes del Conventus Cluniensis. Guipúzcoa no ha dado ninguna dedicatoria, y una Vizcaya, la ya mencionada consagración a Luvilae.

Piensan N. Dupré y M. J. Peréx Agorreta que la repartición de los testimonios votivos está en función del trazado de las calzadas, como se deduce del hecho que los teónimos del norte de la provincia de Burgos, ninguno de ellos referentes al culto a las aguas, se han recogido en la via Asturica-Burdigala o en la de luliobriga (Reinosa) a Salionca (Poza de la Sal), que alcanzaba a la primera en Tritium Autrigonum (Monasterio de Rodilla). Lo mismo cabe afirmar de los límites de las provincias de Burgos, Álava y La Rioja según estas autoras. La ciudad de Virovesca (Briviesca) se encontraba en el cruce de las vías Asturica-Burdigala y de Italia in Hispanias. Atravesado el Ebro la primera calzada pasaba por Arcaute, Iruña, Alegria y Artaya. La segunda cruzaba Libia de los Berones, Tritium Megallum (Tricio), y Vareia (Varea), para llegar al Ebro por Agoncillo y Alcanadre hacia Caesaraugusta. De esta última ciudad una tercera via partía a la capital de Lusitania, Augusta Emerita. Todas estas vias están citadas en el Itinerarium Antonini. Los itinerarios dan a conocer algunas vías transversales.

Las vías romanas favorecieron los establecimientos más próximos. Las grandes termas medicinales se sitúan en los confines de dos (Tiermas) o de tres (Fitero) grupos étnicos en regiones fronterizas.

En las dedicatorias ha quedado constatada la procedencia de devotos. Así, en una inscripción a las ninfas de Leyre, o de Tiermas, en territorio vascón, el oferente es un berón, oriundo de Vareia, que era aquilegus.

${ }^{38}$ Blázquez, J. M., Religiones primitivas, 176; Id., Diccionario, 111. 
En Cabriana, la inscripción a Varnae está dedicada por Antonius Flauos Ne[r?]uiensis, por la salud de Estiterus (?). En Ujué Lacubegi recibió culto de Festa, nombre latino, en compañia de Coeli Tesphoros y de Telesinus, ambos de origen oriental.

En Ujué se veneraba un dios local de carácter acuático, al igual que en Rasillo de Cameros a Caldo Uledico, cuya naturaleza de dios medicinal de carácter acuático, como lo indica la primera parte del nombre, es seguro. Se fecha esta última inscripción a final del siglo I, o a comienzos del siguiente.

La Interpretación romana se documenta también en esta zona. En Aquae Bilbilitanorum a la divinidad de las aguas termales se la denomina simplemente deus, mientras reciben el nombre de genius y de Tutela en las zonas más romanizadas. Todos estos datos indican un sincretismo religioso grande.

En las dedicatorias de Cabriana se siguen bien los pasos de este sincretismo. Una inscripción está dedicada a Varnae o Uvarnae; una segunda a las Nymphis bonis et locos y una tercera a las Nymphis simplemente.

Las ninfas cuentan con seis inscripciones sobre doce entre las dedicatorias a las aguas, en el norte de Hispania. Las dedicatorias a las ninfas ocupan el segundo lugar entre 57 inscripciones votivas. La región septentrional se aproxima en este aspecto más al noroeste que al noreste, donde se documentan Apollo, Tutela y Esculapius, dioses también vinculados con las aguas, aunque en el noreste también han aparecido teónimos indigenas como Lung- ${ }^{39}$, en Peñalba de Villastar (Teruel); Neitin en Binefar, y Deo Heterotago en Cataluña.

Los devotos rinden un culto a diferencia de lo que sucede en Occidente, asociado al de un dios romano. Los romanos dan culto a dioses indígenas, y al revés, lo que prueba un sincretismo muy avanzado. Estamos totalmente de acuerdo con $\mathrm{N}$. Dupré y con M. J. Peréx Agorreta que «il est difficile de lier -comme on le fait parfois-la présence de Théonymes indigènes à la résurgence d'un indigénisme local et au recuil a la romanisation, aprés la crise du III siècle ${ }^{40}$. Dans la zone septentrionale en tout cas, une telle réaction ne semble pas perceptible et c'est au contraire du IV siécle que datent les plus riches villae de la région de l'Ebre». Muchas veces los dioses indígenas tienen dedicantes romanos.

${ }^{39}$ Bläzuez, J. M., Religiones primitivas, 89,91 ss, 226; Id., Diccionario, $117 \mathrm{ss}$; Id., Primitivas religiones, 224,253 ss.

${ }^{40}$ Blázquez, J. M., Nuevos estudios sobre la romanización, 573 ss. Hoy día creemos que no se puede hablar de rechazo de la romanización. 
Aunque no se relacione directamente con los balnearios, es importante recordar la Diadema de San Martín de Oscos (Asturias), donde posiblemente se describa un ritual de un culto acuático, que consistía en una procesión de jinetes y soldados que levantaban en alto sus escudos y puñales, la cabeza defendida con cascos de cuernos. Unos hombres de a pie transportan unos grandes calderos, que debian contener agua; ciertas aves comen peces, que se encuentran también debajo de los caballeros. Otros animales semejan ranas; incluso la acción se sitúa dentro o cerca de un rio, pues se representa el agua y animales acuáticos. G. López Monteagudo ${ }^{41}$, que ha estudiado bien esta excepcional pieza, escribe que «indudablemente se trata de una ceremonia religiosa en la que el agua juega un papel importante».

\section{RESUMEN}

En este trabajo se recogen los testimonios más recientes sobre el culto a las aguas en la Hispania romana. Partiendo de los últimos hallazgos, se hace una breve referencia a los balnearios peninsulares, con sus posibles identificaciones, testimonios epigráficos y restos arquitectónicos más representativos. Del estudio del culto a las aguas en época romana, se puede descubrir la pervivencia de los cultos indigenas, el sincretismo religioso y la aculturación romana de la sociedad indígena.

\section{ABSTRACT}

This report contains the most recent findings about the water cults in Roman Spain. Starting with the last discoveries, we make a quick reference to the iberian spas, including their possible identification, epigraphic testimonies and the most representatives architectonic ruins. From the cult to water during Roman times, we can follow the survival of the native cults, the religious syncretism and the Roman aculturization of the native society. 99 y ss.

${ }^{41}$ "La diadema de San Martín de Oscos», Homenaje a Garcia y Bellido III. Madrid 1977, 


\title{
Iconografía y culto a las aguas de época prerromana en los mundos colonial e ibérico
}

\author{
Ricardo Olmos * \\ ...«qué bien sé yo la fuente que mana y \\ corre \\ aunque es de noche"...
}

San Juan de la Cruz

En esta comunicación voy a centrarme en algunas referencias, principalmente textuales e iconográficas, sobre el culto a las aguas durante la época prerromana en la Península Ibérica, centrándome en los mundos coloniales e ibérico. Hasta la fecha no existe sobre este tema un trabajo de síntesis, si exceptuamos un amplio artículo de José M. ${ }^{a}$ Blázquez, pero referido principalmente a época romana (1977: págs. 326-7).

La documentación de los anteriores momentos orientalizante e ibérico es escasa y dispersa y, en no pocas ocasiones, de tipo conjetural. Por ello es en algún caso necesario traspolar a la Península esquemas más universales y mejor conocidos del Mediterráneo antiguo; o, bien indirectamente, proponer conjeturas, basadas en datos de época posterior y de la misma etnografia, para aplicarlas a este momento más temprano en que los testimonios directos faltan. Además, especialmente en el caso de la documentación iconográfica, vamos a encontrarnos ante un testimonio ambiguo. Todo ello supone unas limitaciones y una inseguridad. Veremos enseguida por qué. C.S.I.C.

* Departamento de Historia Antigua y Arqueología. Centro de Estudios Históricos, 
Me referiré, primero, al mundo colonial. En la presencia comercial y colonial de los pueblos mediterráneos en la península -fenicios, griegos y púnicos- se rastrean determinados ritos vinculados a las aguas, generalmente en lugares costeros. En su relación con el comerciante mediterráneo el agua puede cumplir simultáneamente varias funciones -religiosas, comerciales y curativas - que se interrelacionan e integran mutuamente. Pero hemos de ver una primera e inmediata función práctica y vital en el agua como es la de dar de beber al navegante que accede al manantial costero para aprovisionarse. La tripulación de marinos fenicios o griegos que se adentraban en el Atlántico tras pasar las Columnas de Hércules, buscarian ante todo -es lógico suponerlo- el lugar, juridicamente protegido, para una fácil aguada. Ya en el mundo mediterráneo del temprano arcaismo conocemos bien esta preocupación primordial del navegante por la Odisea $(X, 56)$ o por posteriores referencias de periplos como el de los Argonautas. La realidad se cuenta, según es habitual, a través de mitos como en la historia de Hilas, el amante de Herakles que al desembarcar se perdió en el país de los misios cuando "buscaba la corriente sagrada de una fuente" (RoDıo, Apolonio, Argonaúticas, I, v. 1.208); o la disputa, sin duda por el agua dulce, que mantuvo el argonauta Polydeukes con el poco hospitalario Amykos, el Rey de los Bébrices (RoDIO, Apolonio, Argonaúticas, II, vv. 1-97). Sólo él controlaba el manantial que, tras su derrota, vemos usar libremente por los griegos en la versión grabada de la famosa cista etrusca «Ficoroni» (SCHEFOLD, K. y JUNG, F. 1989; pág. 28, fig. 28).

En la Península Ibérica los santuarios costeros, que citan las fuentes - por ejemplo, Estrabón o la tradición que recoge el tardío periplo de Avieno- debieron estar en su mayoría vinculados a manantiales de agua dulce. En este sentido podría ser significativa una conjetural presencia de ofrendas, como son los cascos de bronce, en ríos del Sur atlántico andaluz como el Guadalete, donde apareció un casco de tipo corintio de la primera mitad del siglo vil a. C. (RuIz Galvez, M. ${ }^{2}$ L. 1985; Olmos, R. 1989, pág. 512); o el ejemplar, más tardío, de la desembocadura del Guadalquivir, que es un ejemplo dudoso pues proviene del comercio de antigüedades (colección privada, Madrid, inédito); y, finalmente, el casco de la Academia de la Historia, datado como el anterior a mediados del siglo vII a. C., descubierto al dragar el estuario del Odiel en la ría de Huelva (OLMOS 1988).

A la función primaria de beber, reglada jurídicamente por leyes "supraétnicas" y reconocidas por todos como la de hospitalidad o philia y la de asylía o derecho de asilo y de protección al extranjero, podrian asociarse funciones en las que el agua adquiere otras significaciones simbólicas y culturales: por ejemplo, la oracular que, según referencias de 
autores como Estrabón $(I I I, 1,9)$ se vinculaba a héroes como Menesteo y que suponemos podría revestir, junto a la acogida religiosa, respetada por todos, una paralela función informativa al marino que llega, bebe y consulta en el oráculo las condiciones, jurídicas y políticas, de los intercambios comerciales o requiere los consejos necesarios para el camino que aún le resta hasta el Extremo Occidente. Desde A. Schulten (1943, pág. 32) este lugar oracular, asociado al nombre de Menesteo, se localiza precisamente en la desembocadura del Guadalete lo que tal vez vincula el lugar sagrado de las fuentes escritas al hallazgo del temprano casco de tipo corintio ya citado. Pudo ser la ofrenda propiciatoria o el exvoto de un marino al traspasar un límite, como el yelmo que en su viaje al occidente ofreció Ulises a la divina pareja infernal «suspendiéndolo en el capitel de una columna" tras asomarse a los umbrales de su mundo soterráneo (Licofrón, Alexandra, vv. 710-711).

En honor del héroe ateniense Menesteo celebraban los gaditanos sacrificios como nos dirá en otro lugar Filóstrato (Vida de Apolonio V, 4). Tal vez, con ello se quiera sugerir una tradición que remontaría probablemente al siglo $\vee$ a. C., en la que Cádiz establece unas estrechas relaciones comerciales con Atenas, lo que tenemos ya documentado por la cerámica ática de este periodo distribuida por el Suroeste peninsular. ¿Controlaba Cádiz el santuario-oráculo de Menesteo, al otro lado de la bahía, en el Guadalete - allí donde se localizan hoy las ruinas de la Torre de Doña Blanca- y con ello todo el comercio de Grecia en el extremo occidente? Parece lo más verosímil.

Santuario y manantiales maravillosos se asocian también en el Heracleion gaditano: recordemos las menciones de Estrabón y Plinio a la fuente de agua potable a la que se accedía descendiendo a través de unos peldaños y cuyo régimen variaba en sentido contrario al de las mareas (Estrabón, III,5,7-8; Garcia Y BelLido, A. 1964; BonNet, C. 1988). Su caudal alternante, su flujo variable según fuera de día o de noche, era considerado como un hecho milagroso, como uno de los mirabilia o paradojas recogidos en la literatura paradoxográfica de la antigüedad y a los que autores racionalistas como Estrabón tratan de dar una explicación natural. Este régimen irregular pudo conllevar un carácter profético, oracular, como en las famosas Fontes Tamarici de Palencia citadas por Plinio ( $N H$ 31.23-4; Garcia y Bellido, A. y Fernández de Avilés, A. 1964). Pero en el culto fenicio del Heracleion de Cádiz esta doble fuente hubo de cumplir una función sagrada y fecundante como la que conocemos que tenía en Sidón el curso de agua con una piscina del Trono de Astarté en el templo de Eshmun, bien estudiado por Dunand (1971:19-25), o la de la fuente en el santuario de Tiro, tal vez modelo estructural de la del Haracleion ga- 
ditano, que recientemente menciona Corinne Bonnet en su estudio sobre Melqart $(1988,209)$.

Agua y santuarios se asocian repetidamente en el mundo fenicio-púnico del occidente. En el santuario púnico de la cueva de Es Cuieram, en la isla de Ibiza, hay vestigios de agua que debieron en su día asociarse al culto de la divinidad femenina de la fecundidad, Tanit, como propone M. ${ }^{a}$ E. Aubet $(1982,10)$. A su vez, en el santuario de la Illa Plana, en la islita situada a la entrada del antiguo puerto de Ibiza, la cisterna romana que documentó Mañá en las excavaciones de 1953, podria responder también a una anterior estructura sagrada vinculada al agua (HACHUEL, E. y MARI, V., 1988; pág. 21). Pero la documentación arqueológica es aqui muy escasa. En todo caso, el culto de Illa Plana parece de tipo fundacional y de origen fenicio antiguo y en él se asociarian posiblemente funciones fecundadoras y curativas, como sugieren la tipología de algunas terracotas vinculadas, tal vez, a ritos de incubatio: son modelos de pequeños lechos individuales, bajos, aislados $y$, esporádicamente, con personajes dormidos (HACHUEL, E. y MARI V. 1988; lám. VI). No sabemos si corresponde su culto con el de Eshmún, cuyo sacerdocio ebusitano dejará huellas, muchos siglos más tarde, en uno de los testimonios epigráficos de la Cueva Negra de Fortuna, Murcia, sobre cuya inscripción (SACERDOS ASCVLEPI EBVSITANI) nos ha hablado anteayer mismo, y documentadamente, Antonino González Blanco (Mangas, J., et alii 1991; pág. 148, n. ${ }^{\circ} 489$ ). Aludiremos más adelante a las cuevas-santuario ibéricas.

En Ampurias, el agua adquiriria una similar función curativa, posiblemente también a través de la incubatio, en torno al santuario de Asclepio. En torno al Asklepieion ampuritano se desarrolla una canalización de aguas, similar a la documentada en otros santuarios helenistico-romanos de esta divinidad en el Mediterráneo (FAUTH, W. 1979: col. 645, con bibl.). Pero en Ampurias la imagen del dios finalmente se deposita en una cisterna de la Neápolis (GARCiA y BelLido 1948: vol. II, págs. 130-134, láms. LVII-LX). No deja de ser significativo este destino final del Asclepio sanador del helenismo ampuritano condenado al agua purificadora y curativa de aquellas mismas cisternas cuya salubridad durante siglos el dios pudo haber protegido. Ello querría decir que quien allí depositó la estatua seguía creyendo en el poder sagrado de las aguas a las que finalmente se encomienda o se condena a la misma efigie del dios. Es habitual, por otra parte, esta vinculación de las imágenes, de las estatuas, con ciertos cultos a las aguas en la antigüedad, donde se colocan y depositan éstas una vez destruidas. En este mismo Coloquio Lorenzo Cara Barrionuevo y Juana María Rodríguez López propusieron hablar de una escultura romana asociada al manantial de Alhama en Almería (cf. el resumen de su comunicación). Recordemos también, entre otros muchos ejemplos, algunas 
de las esculturas de la Villa Romana de El Ruedo, en Almedinilla, Córdoba, destinadas a ambientar el entorno de estanques y de fuentes y que son, finalmente, arrojadas a las aguas (VAQUERIzO, D. 1990: pág. 315 «esta práctica resulta habitual en la antigüedad tardía»).

El significado de este rito es posiblemente ambiguo y por tanto multivalente. Conservamos testimonios de numerosas noticias sobre esta costumbre, leyendas que perviven durante siglos en la tradición popular, como es el caso de la famosa «Bocca de la Verità» en el contexto de la Roma medieval, o incluso de algunas de las estatuas de Venus (D'ONOFRIO, C. 1990: págs. 11-24). Entre el agua y la estatua se establece una relación mágica pues ésta se concibe como algo vivo, a la que se puede ahogar o condenar al frío y humedad de aquélla (D'ONOfRIO, C. 1990: pág. 14). Por estudios etnográficos conocemos algunos rasgos de estos rituales, que siguen hoy día documentándose en pueblos españoles. Se ha estudiado la función hidrófora de algunas imágenes de santos y más de algún santón de iglesia, como San Pedro Apóstol, San Blas, San Marcos y San Bernabé han podido acabar en el pilón del pueblo o en el río vecino por no atender en su momento una imploración de lluvia de la colectividad, que así le paga (Domínguez Moreno, J. M. ${ }^{a}$ 1987: pág. 14). Se trata con gran verosimilitud de un residuo pagano como ha señalado muy recientemente, sobre todo con relación a la Rioja, Rosa Maria Valdivieso Ovejero (1991: págs. 91-94).

Pero sigamos con Ampurias. La iconografía de algunas de las más conocidas emisiones de las dracmas ampuritanas deberia revisarse un día en profundidad. Se ha dicho que el modelo de algunas de ellas es la cabeza de Aretusa rodeada de delfines. Se inspiraria, directamente o no, de las famosas acuñaciones de Siracusa con la imagen de la ilustre ninfa fugitiva quien, al asomar su cabeza, se ofrece como manantial sagrado de agua dulce que da de beber a la ciudad. Desde luego la imitación de un motivo formal nunca implica una paralela o simultánea adaptación de un contenido: sería un trasvase mecánico, lo que no suele darse en las monedas (GARCíA-Bellido, M. ${ }^{a}$ P. 19S2). Por tanto, la cabeza femenina de las acuñaciones ampuritanas debe referirse a una divinidad o ninfa local que protege el asentamiento colonial y nunca a las "Aretusas" y otras ninfas de los modelos, como ya señaló M. ${ }^{a}$ José Pena (1973). Se ha propuesto, y parece correcto, que se trata de la Artemis ampuritana o de una divinidad que adopta atributos de diosa frugífera, similares a Tanit, en una cierta koiné comercial y de pensamiento con el mundo púnico (PENA, M. ${ }^{a}$ J. 1973; Garcia-Bellido, M. ${ }^{\text {a }}$ P. 1990, págs. 75-78; eadem 1992, en prensa). Sea Artemis, Tanit o una ninfa local ampuritana esta imagen pudo relacionarse con el agua y con la fecundidad que a través de ella la divinidad otorga a la ciudad. También podríamos pensar en algún mito occidental 
que nos relacionaría anverso y reverso de estas acuñaciones. El caballo alado del reverso, el Pegaso saltando y, en ocasiones, con la variante de su cabeza transformada en el cuerpo de un pequeño niño -el unas veces mal llamado Cabirion y otras, más correctamente, Crisaor- (VILLARONGA, L. 1979 (1987), 98, n. ${ }^{\circ}$ 183) podria aludir a la fuente que brota en el lecho del amor de un dios marino con una ninfa local. En la versión más conocida éstos eran los mismos Posidón y la hermosísima Górgona -la clarissima forma de la tradición literaria- cuyos cabellos originarios, luego convertidos en serpientes, constituian la prenda más hermosa de su cuerpo (Ovidio, Metamorfosis, IV, vv. 794-797).

Recordemos además que es propio de las divinidades fluviales su capacidad continua de metamorfosis (NiNCK, M. 1921: págs. 148 ss.,) lo que sería también una pista o indicio para explicar iconográficamente la presencia del enigmático niño de los reversos emporitanos. Doble fruto de ese furtivo amor divino serian aquí el monstruo alado y el niño, metamorfoseado éste al instante en caballo. Como en todo mito local griego este ser mixto será dador de fecundidad a la colectividad: el manantial. Similares historias locales se contaban en Grecia: en el Helicón, donde Pegaso habría hecho manar la fuente Hipocrene (etimológicamente «el manantial del caballo») (Pausanias, Descripción de Grecia, IX, 31, 3; OVIDIO, Metamorfosis V, vV. 256-263); en Trecén, la llamada «Fuente del Caballo» (PAusanias, Descripción de Grecia, II, 31, 9); y, sobre todo, en Corinto, donde Pegaso sería el origen de la fuente Pirene que brota en el lugar alto de la ciudad y que, por tanto, figura desde el arcaísmo y hasta los años finales del siglo IV a. C. como símbolo de sus monedas (JENKINS, G. K. 1972: pág. 51, n. ${ }^{\circ s} 73-4$; MoRKHOLM 1991, pág. 87). Ya en la antigüedad se asociaba etimológicamente el nombre de Pegaso con el de la fuente pegé y sabemos bien que las mismas palabras con frecuencia suscitan mitos. En el caso de Ampurias esta conjetura debería de apoyarse hoy en la constatación de manantiales que abastecieran a la ciudad. En un lugar situado entre San Martín y la Neápolis, pero en una zona que en la antigüedad estaba cubierta por agua de mar, el Dr. Enric Sanmartí nos contaba el haber bebido hace unos años él mismo de un venero de agua dulce que brotaba de la arena, a nivel del mar ¿fue acaso también nuestro Pegaso, en este lugar o en otro próximo, huius origo fontis?».

También debe quedar abierta en este sentido, como sugestivamente ha propuesto M. ${ }^{a}$ Paz García-Bellido, la significación del toro androcéfalo, un Aqueloo, que decora algunas tempranas emisiones en plata, ya en el tránsito a la metrología ligera de la dracma, en Arse - Sagunto- (VILLARongA, L. 1987, pág. 134, n. ${ }^{\circ} 307$; Garcia-Bellido, M. ${ }^{a}$ P. 1990, págs. 8389). El toro humano vuelve la cabeza barbada hacia el espectador en un gesto de comunicabilidad de la naturaleza con el hombre, con el ciuda- 
dano. ¿Se trata aquí también de la personificación del río local que fecunda las tierras saguntinas y da de beber a la comunidad? Es muy probable que así sea. Ya en un plano mucho más hipotético creo que debe permanecer la vinculación de la Bicha de Balazote con éstas u otras imágenes coloniales (Garcia-Bellido, M. ${ }^{a}$ P. 1990, págs. 85-87). Me parece aún oscura e incierta su interpretación sincrética con un culto funerario vinculado a la fecundidad de las aguas: la cierta proximidad formal de este toro andrósopo con el Aqueloo griego, que en 1931 sostenía ya A. García y Bellido, no implicaba automáticamente una proyección paralela -ni siquiera secundaria- del contenido. Vemos hoy en esta escultura, sobre todo, la imagen arcaica de un demon funerario local de raíces mediterráneas que decora y protege, como sillar de esquina, un monumento turriforme mientras que el toro androcéfalo de las acuñaciones de Arse responde al período del helenismo mediterráneo. Es éste un momento histórico y cultural muy diferente, y han podido revivirse y recrearse con nuevo gusto erudito viejos mitos y leyendas que se dotan ahora de un claro sentido etiológico en relación con la naciente ciudad filohelena. Aquí sí tendría cabida la personificación benefactora del río local en toro humano.

Pasemos con ello ya al mundo indígena y, concretamente, al ibérico. Conocemos muy poco sobre la identidad de las divinidades locales en época prerromana por lo que, generalmente, solemos utilizar la documentación que conservamos del periodo ya plenamente romano para aproximarnos a esta situación anterior. Se ha supuesto que la asombrosa multiplicidad de teónimos documentados en la Península lbérica durante la época romana - sobre todo en áreas no ibéricas - responde a una tradición prerromana, donde existiria una extraordinaria abundancia de démones y divinidades locales, de Genii loci. Así, la amplia variedad de ninfas cuyos epitetos locales conocemos por la tradición romana se debieron asociar a fuentes y a aguas medicinales en uso durante el período anterior (CURCHIN, L. A. 1991: pág. 159). Partimos pues del enorme conservadurismo religioso en este campo con divinidades de carácter utilitario y funcional vinculadas desde tiempos ancestrales al lugar. Todo ello parece también confirmarse desde el punto de vista de los estudios de carácter etnográfico que indican cómo, por ejemplo, las ninfas y sirenas han pervivido hasta relativamente hace pocas décadas en la tradición popular de numerosas regiones españolas (CURCHIN, L. A. 1991: 1.C; JURASTI, V. 1944: págs. 26-27; DíAZ DE VIANA, L. 1983: tomo I, pág. 100; Olmos, R., 1989 b: pág. 44). Ello nos introduce en el carácter numénico $y$, por consiguiente, apenas antropomórfico, de una gran parte de la experiencia religiosa ibérica cuyos lugares y formas de culto ha definido Rosario Lucas como loca sacra libera, si aceptados esta analogía, trasladada de la re- 
ligiosidad romana, en nuestro ámbito (BLÁzQUEZ, J. M. ${ }^{a}$ 1957: pág. 85; Idem 1959: pág. 83 ss.; LuCAS, M. ${ }^{a}$ R. 1981: pág. 238).

Sabemos la gran importancia que el culto del agua tuvo en los santuarios ibéricos, al asociarse espacialmente a manantiales y a fuentes, a veces de carácter curativo como ha señalado Mónica Ruiz Bremón para el Cerro de los Santos o José Antonio Morena para el de Torreparedones, en la provincia de Córdoba o, en general, José María Blázquez para los santuarios andaluces como el de Despeñaperros o el del Castellar de Santisteban, entre otros (BLÁQUeZ, J. M.a 1991: págs. 24-26; RuIz BREMon, M. 1987: págs. 186-188; MorenA, J. A. 1989: págs. 46-47). Otro tipo de santuarios, que entroncan con tradiciones muy anteriores de la Edad del Bronce, se sitúan especialmente en los ámbitos valenciano y del Sudeste y su culto se ha puesto en relación con la presencia fecundadora del agua. A aquél se vincularían según sus estudios pequeños vasitos cerámicos como ofrendas, de época ibérica (GIL MAscareLL, M. 1975; EAD 1977; LuCAS M. ${ }^{a}$ R. 1981: pág. 239). Diacronía y sincronia deberán relacionarse con más profundidad para ver la interacción de la tradición heredada del Bronce y el coetáneo influjo de modelos coloniales, como se apunta, al menos para un momento ya tardío, en el citado caso de la Cueva Negra (cf. supra).

Parecen, pues, asomar datos importantes pero aún, por desgracia, éstos sólo nos sirven como aportaciones demasiado generales que poco añaden al modelo genérico ya conocido. En cambio, apenas se ha estudiado la función que tuvieron los grandes santuarios interlocales vinculados a manantiales en la definición de los modelos territoriales, su colocación estratégica en vías de comunicación o en lugares de control de la trashumancia, su función aglutinadora interétnica, y la interacción social del culto al agua con instituciones jurídicas de la religiosidad indígena, como pactos políticos y comerciales entre poblados, pactos matrimoniales o simples ritos de iniciación. Este proceso, en el que el culto de las aguas y la regulación comunitaria de su uso interviene siempre en cada santuario de manera dialéctica y nunca de manera mecánica y unificadora, se ha estudiado en cambio con más profundidad en el mundo itálico, por ejemplo en relación con los santuarios lucanos y daunio-samnitas (MASSERIA, C., en prensa). No obstante, se están apuntando indicios en algunos de estos sentidos en santuarios como en el Cerro de los Santos, cuya función social ha puesto de relieve, reciente y sugestivamente, Encarnación Ruano (1988). En la línea apuntada por esta autora las grandes esculturas de oferentes no tendrían tanto - 0 tan sólo- un sentido de exvoto curativo - sin excluir éste- como sí pudieron ser en cambio expresión de una manifestación social de determinados pactos a través de la imagen. Algunas de las esculturas del Cerro de los Santos podrían 
Iconografía y culto a las aguas de época prerromana ...

ser pues la materialización plástica de determinados pactos matrimoniales, o de ritos iniciáticos en los que la ofrendante se reviste de todas sus joyas y vestidos para materializar mediante la ofrenda de la imagen ese momento, elegido y único, del tránsito (Fernández, M. 1992, en prensa). Pues es función prioritaria del santuario regular, sellar y sancionar el pacto ante las diferentes comunidades ibéricas que alli se dan cita. El conjunto de las esculturas en ellos ofrecidas constituiría pues la plasmación del universo imaginario que se construye en torno a la regulación jurídica y sacral del agua. No interesa tanto la imagen de la divinidad del lugar como de las personas en ellas representadas cuyo status nos definen cuidadosamente los elementos materiales - joyas, vestidos, armas, gestos- en el marco de una "cultura de vergüenza" si la aplicación del término anglosajón «shame culture» es aquí el adecuado.

Las escasas sugerencias que se han propuesto sobre representaciones del agua o de su culto no son, ni mucho menos, seguras. Así, desde A. Garcia y Bellido, se ha interpretado conjeturalmente una terracota de un tipo muy esquemático y similar a las del grupo de la Serreta de Alcoy, pero procedente de Verdolay, en Murcia (1976, fig. 374, pág. 483). Se trata de una casi informe figurita humana, posiblemente inclinada ante un recipiente cóncavo: «parece adivinarse, dice Bellido, una mujer al borde una fuente sagrada?", frase que autores posteriores consideran como un testimonio más documentado del culto a las aguas (LuCAS, R. 1981: pág. 239; BLÁZQUEZ, J. M. ${ }^{a}$ 1977: pág. 327). Yo no he realizado una autopsia del documento, que considero necesaria, pero basándome sólo en la incierta fotografía publicada, no sé si podría tratarse de una imagen de libación. Quede abierta su lectura.

En todo caso, la representación del agua en el mundo ibérico muy rara vez será directa o inmediata. La antropomorfización de la imagen de la fuente, del río o de la ninfa del lugar, e incluso su definición con un nombre abstracto, como es el caso de la Salus Umeritana en la patera de Otañes - que hoy sirve de frontispicio al programa de nuestro Coloquiotodo ello, digo, es un fenómeno secundario ya esencialmente romano. La pregunta que yo formularia hoy aquí podría ser la siguiente: ¿debemos considerar como un fenómeno exclusivamente romano esta innovación que conduce a una antropomorfización del anterior genio o demon numénico en Hispania? ¿o podemos rastrear indicios de este proceso ya en el mundo ibérico anterior a la romanización? Yo creo que sí hubo antecedentes claros de este proceso, pero hoy nos resulta muy difícil rastrear una iconografía directa, es decir no ambigua, del agua. Es preciso definir símbolos y contextos donde se pueda establecer la presencia, en principio anicónica, de este fuerza numénica. Uno de los caminos posibles será el 
rastrear en la imagen la actuación dinámica del agua, es decir sus efectos.

En la cerámica ibérica la iconografía que nos ocupa se simboliza en ocasiones con elementos vegetales pues la vegetación, lo que brota, expresa, como el agua, ese poder dinámico de la naturaleza. Roleos y elementos vegetales son en ocasiones símbolos que representan sin ambigüedad el agua: por ejemplo, debajo de las patas de los hipocampos en un gran vaso de los Villares en Caudete de las Fuentes, en Valencia, una sucesión de roleos horizontales simbolizan con claridad las olas del mar; pues a continuación vemos en el mismo vaso cómo estos roleos horizontales se transforman en naturaleza vegetal que brota verticalmente, ya en un ambiente o contexto de tierra (PLA E. y LACOMBA, E. 1980: págs. 99-106, lám. XLII-XLIV, fig. 12; Olmos, 1989 b: págs. 49-50, figs. 1-18). La vegetación como agua es, pues, en ese contexto, inequívoca.

De un modo similar, en los platos de pescado iberohelenísticos el elemento vegetal es, a la vez que agua en la que nadan los peces, naturaleza engendradora y nutricia en la que aquéllos pican. Vemos pues en estos ejemplos cómo el agua se define simbólicamente con elementos vegetales es decir, no directamente sino siempre a través de lo que nosotros consideramos sus efectos, su acción en la naturaleza. Ello corresponde bien con el poder metamórfico y dinámico del agua. Podriamos en consecuencia postular la presencia de cultos o mitos relacionados con el agua en numerosas escenas y sin que aquélla se describa directamente: por ejemplo en los bronces de Máquiz, donde dos personajes míticos -dos de ellos definidos con rasgos de tritón- elevan sus brazos propiciando el brotar de la naturaleza (Almagro BASCH 1979; OLmos 1989 b: págs. 47-49). Son démones del agua posiblemente en su relación con la fecundidad en ultratumba, sin que podamos ya definir si la escena tiene lugar en un contexto de agua marina o de fuente. Tal vez esa diferenciación fuera irrelevante para el ibero del interior.

Otros ritos de propiciación de la vegetación que brota exuberante son bien conocidos en las cerámicas de Alcorisa y Azaila, en Teruel: implican de hecho el culto a un manantial que no vemos representado pero sí sugerido en su efecto generador, en las grandes flores que brotan verticales (Pericot, L. 1979: figs. 406-411). Escenas como la de Pozo Moro con el inmenso árbol de la vida en el que anidan pájaros y que protegen con largos tenedores seres míticos son una expresión ibérica del Jardín o Paraiso al que solo accede el héroe (Almagro GorbeA, M. 1978: pág. 265, lám. 5,3; Idem, 1983, pág. 202). El sentido simbólico de esta iconografía, rastreable ya en el mundo tartesio - placas de cinturón de Niebla (Huelva) o Sanchorreja (Ávila) (BlaqueZ, J. M. ${ }^{a}$ 1975: págs. 88-89, figs. 31-32)- 
es paralelizable con muchos otros ejemplos del ámbito mediterráneo, como el etrusco: el héroe es símbolo y modelo del aristócrata alli enterrado y sólo él se asocia al árbol que da fecundidad a la comunidad que representa (MENICHETTI, M. 1988: pág. 108, fig. 33: «Stele Zannoni, Bologna»). Microcosmos y macrocosmos, hombre y naturaleza, individuo y comunidad, se corresponden y relacionan a través de este símbolo pregnante del «árbol universal» que fecunda el agua (Toporov 1973: págs. 171172). De este modo, podríamos leer muchos otros ejemplos más tardíos de la plástica ibérica como la estela con la palmera y la cierva y su cría, de Osuna, hoy en el Museo Arqueológico de Sevilla (CHAPA 1985: lám. XIX, n. 112; Almagro Gorbea 1983, pág. 237, lám. 33b; Olmos et alii, 1992, n. ${ }^{\circ}$ $53,2)$. La cierva alarga su cuello para alcanzar los dátiles de la palmera mientras que el cervatillo, a ras de suelo, mama de las ubres maternas, nutridas por un árbol que regó el agua y engendró la tierra: en esta imagen de la naturaleza cíclica en que las diversas esferas se comunican -en su doble movimiento, a la vez ascendente y descendente - hay también implícita una metáfora de la vida humana, una «nostalgia de la totalidad» utilizando la expresión del semiólogo de la escuela soviética Toporov (1973: pág. 172): de ahí su sentido funerario.

El agua no está figurada directamente en estos ejemplos de la plástica ibérica. No es necesario hacerlo. Le basta al escultor manifestar sus efectos sensibles y fecundadores en el gran árbol por aquélla regado. Recordemos la iconografía oriental del Paraíso del que el agua es siempre fons et origo.

El fluir del agua está oculto a nuestro ojos. Pero subyace aquél en decenas de imágenes ibéricas, por ejemplo, a través de la vegetación exuberante en los vasos de Elche y de Archena, vegetación que justifica el brotar de flores y con ella de animales - especialmente lobos y águilas-a la vida (Olmos, R. 1987: págs. 25-28, fig. 3; Olmos 1990; Olmos, R. et alii, 1992: n. ${ }^{\text {s }} 69$ y 70). Cuando en esta decoración abigarrada aparece el espacio reservado a una incipiente divinidad antropomórfica — la diosa que brota entre tallos vegetales como el tallo de una flor-podemos postular los inicios de un influjo mediterráneo que da forma humana a esta imagen originariamente numénica de la naturaleza que fecunda el agua. Posiblemente el mediador púnico influye de forma decisiva en estos ejemplos de diosas brotando de Elche, a las que se sitúa bajo unas ficticias asas (Olmos 1990, láms. 10 y 11,3). Estas asas crean así el espacio sagrado de un templo o de un simple nicho cultural, que se reserva a la efigie divina. Pero la diosa no es causa del brotar de esa exuberante vegetación sino un efecto más, pues aquélla se despliega espontáneamente, es autónoma. De ahí, tal vez también la paradójica multiplicidad de imá- 
genes divinas que coexisten en un mismo vaso y la acumulación, en ocasiones, de rosetas.

En un vaso iberohelenístico de Elche, publicado por Rafael Ramos (1989; Olmos, R. et alii, 1992, n. ${ }^{\circ}$ 70) la diosa, de rostro frontal, brota entre pájaros que acuden a picar a ambos lados del rostro, en las alas y orejas, como en una flor. La imagen, pues, relata el nacer de la diosa como planta, en aquél juego continuo entre la antroposfera y la cosmosfera que vimos ya sintetizadas en los motivos del «árbol universal» (Toporov, $V$. N. 1973, págs. 171-2). Aquí decididamente el símbolo se antropomorfiza, se convierte en mito, en historia divina, con espectadores - dos varones barbados- que, acompañados de una pareja de serpientes, surgen junto a la diosa y la contemplan, como vemos en el reverso del vaso. En este surgimiento hay una lectura vertical del espacio: en el episodio teogónico se sintetizan el mundo aéreo, de las aves, y el inferior subterráneo. El color propio de este último ámbito es el negro, que cubre por completo el cuello y el arranque de los rostros divinos. En la silueta negra que enmarca la barbilla femenina las lineas onduladas definen ese límite de la tierra: una tierra que es, tal vez simultáneamente, naturaleza acuifera y metamórfica. Sólo del agua que torna fructífera la tierra puede brotar, con ese vigor e inmensidad, la diosa. La ambigüedad de este elemento puede, pues, quedar insinuada vagamente en estas imágenes ibéricas, a traves de sus asombrosos efectos.

El modelo de Tanit, impulsado por la influencia púnica en toda área ilicitana durante el siglo III a. C., está detrás de esta incipiente inconografía antropomórfica ibérica. Tanit es también - lo apuntábamos arriba- la reguladora del agua fecundante en los santuarios púnicos. Es posible que, en una creciente comunidad urbana como es Elche, el culto ibérico de esta divinidad que preside la naturaleza vegetal tenga como finalidad la regulación del uso del agua en todo el territorio. La diosa encarna esa presencia sagrada que da de alimentar a la comunidad. Lo que explica, desde el punto de vita económico, político y, por tanto simbólico, la frecuencia de esta imagen divina en los vasos de la Alcudia ilicitana. Podrán ser éstos la expresión de su culto urbano, pero siempre en su relación con el campo.

De un modo similar cabe interpretar los bustos en terracota, considerados pebeteros o perfumadores, con un busto femenino coronado de espigas o frutos. M. ${ }^{a}$ José Pena ha estudiado su difusión, especialmente por el área ibérica del Nordeste español, y los asocia a la influencia ampuritana y a una iconografía ibérica influida por la grecopúnica -o mediterránea occidental - del círculo de Deméter/Tanit (1987, pág. 354). Dos yacimientos, Pontós, en Gerona, no lejos del río Fluviá, y el tarraconense 
de Camarles, junto al Delta del Ebro, recuerdan a la autora algunas caracteristicas de los santuarios siciliotas de Deméter señaladas por Orlandini: «fuori della cità, isolati, a poca distanza del mare, presso la foce di fiumi» (Orlandini, P. 1968-69, pág. 335; Pena, M. ${ }^{a}$ J. 1987, pág. 354). Tal vez un día sea posible precisar más todos estos datos, hoy dispersos, que implicarian una estrecha relación del cultivo del campo, el uso del agua y el culto a la divinidad femenina que protege y otorga la fecundidad agraria.

El mundo griego, que se caracterizó por la antropomorfización constante de su universo religioso, raramente representó el agua como tal sino generalmente a través de su imagen mítica: por ejemplo, el toro humano como río, el Pegaso como manantial y, sobre todo, la ninfa con una hidria vaciándose como fuente. A veces determinados símbolos como la línea de postas o las espirales ambientan en la cerámica griega las escenas de los paisajes marinos. No sabemos si el mundo ibérico recoge en algún momento ese sentido simbólico griego de las postas como ondas de agua, o simplemente como un símbolo más de la vegetación o, incluso, ornamental. Una línea de postas ambienta la conocida escena de caza del vaso Cazurro, que podría ser de hecho un rito de iniciación de dos adolescentes por medio de la caza y la carrera (PERICOT, 1979: págs. 184 y 204, figs. 330-331; Olmos et alii, 1992: n. ${ }^{\circ} 83,3$ ). Pero las ondas pueden sugerir aquí, sencillamente, una simple ambientación de exteriores, una insinuación del terreno o de ese ambiguo mundo vegetal que enmarca la carrera.

Más clara es la escena de la incitación del toro en un vaso de Liria donde las postas subrayan su carácter ritual (PERICOT, 1979, figs. 241-242; OLmos et alii, 1992, n. $\left.{ }^{\circ} 77,3\right)$. ¿Son las postas un simple énfasis decorativo, para llamar la atención visual del rito festivo? ¿o una insinuación espacial más concreta que nos indicaría que este ritual del toro tiene lugar junto a las aguas de un manantial o rio? No lo sabemos con precisión pero si creo que la escena de un modo u stro está en relación con el subrayado de las ondas. En todo caso éstas subrayan el carácter fecundador del ritual taurino.

Ello reforzaria la vertiente masculina de esta divinidad fecundadora, relacionada con el agua, que es el toro y que vemos representado en esculturas funerarias, en vasos y en monedas peninsulares en época prerromana. Enrique Llobregat ha escrito sugestivas páginas en relación con este tema del toro y el culto a las aguas en el levante ibérico (1981). Aquí, una referencia de nuevo al campo etnográfico resulta tentadora. El toro pone en relación los fenómenos celestes con el campo: es el animal propiciador de las lluvias que fecundarán la tierra. Su mugido, se dice po- 
pularmente, las anuncia (Dominguez Moreno 1987, págs. 22-5). De ahí el carácter astral del toro en las monedas de Cástulo que ha estudiado María Paz García-Bellido (1982).
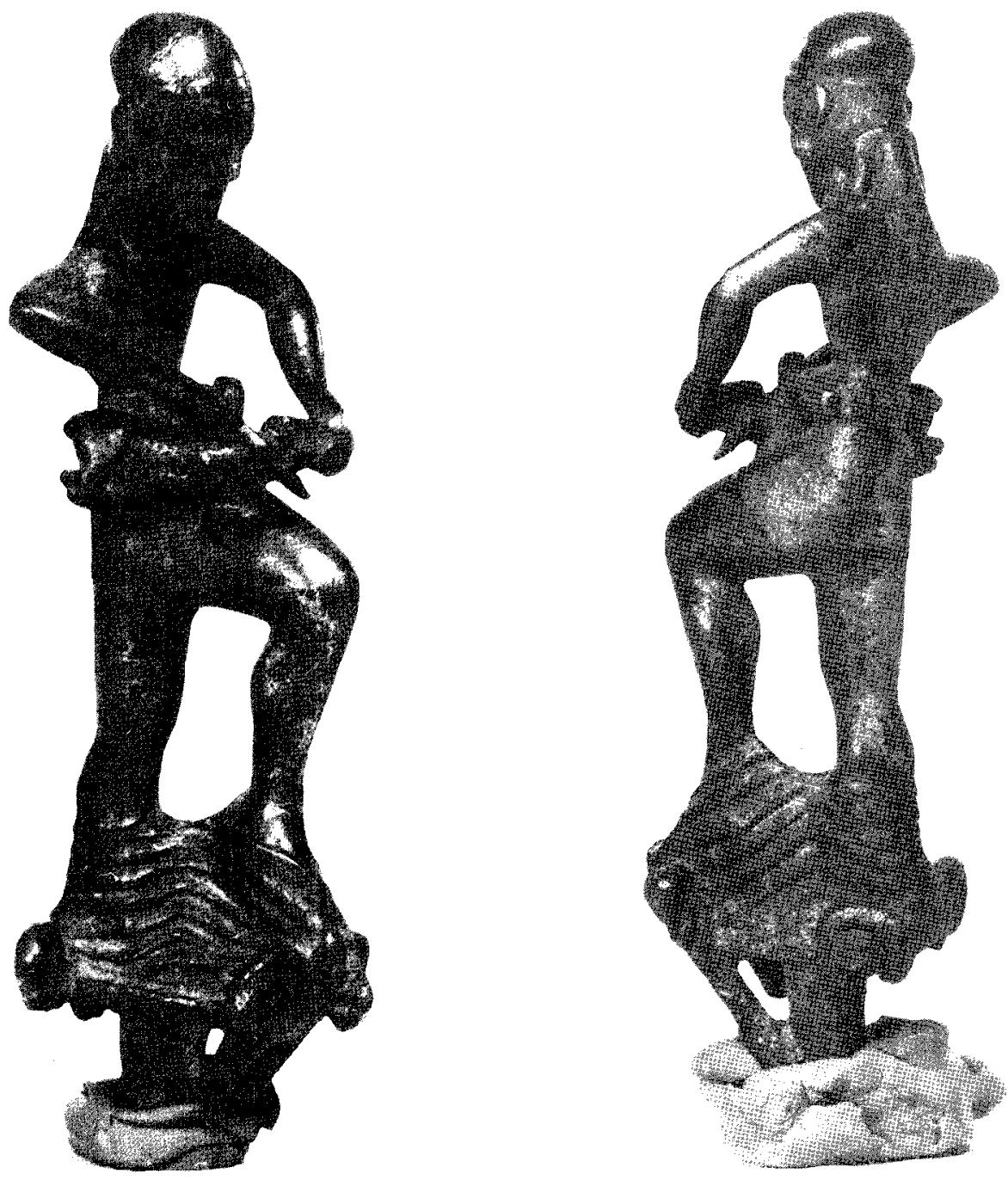
Me queda por último referirme a la única iconografía del agua en el ámbito ibérico que no es ambigua. Me refiero a un conocido bronce del Museo Arqueológico Nacional (inv. 1970/14) (Los Iberos, 1985, n. ${ }^{\circ}$ 107; BlÁzquez, J. M. ${ }^{a}$ 1983, fígs. 67; Olmos et alii, 1992, n. $\left.{ }^{\circ} 86,2\right)$. Un varón degüella con un cuchillo afalcatado a un animal, un pequeño carnero. Unos rasgos iconográficos peculiares caracterizan y resaltan al sacrificante: largos mechones individuales y ondulantes caen sobre los hombros si bien una cinta ciñe la masa del pelo en torno a la frente. Viste túnica corta ceñida a la cintura por un cinturón. Inclina su rostro, atento al acto del sacrificio. Apoya su pierna izquierda, posiblemente sobre una roca, doblada por la rodilla, y la derecha se introduce hasta media pantorrilla en las aguas ondulantes de un manantial o río. Todo ello reposa en un soporte, un vástago sobre el que iba apoyada la totalidad de la escena, que remata en una doble flor, abierta en volutas. Éstas enmarcan el inicio y el final de la corriente, es decir, definen la dirección y los cuatro ejes espaciales que orientan la acción sagrada. Entre los tallos de la voluta anterior asoma el pequeño prótomo de un animal, tal vez canino. Parece como si, asumiendo una función de roca o de escabel, el brote animal estuviera sometido por la pierna doblada del varón, en un esquema bien conocido en el mundo ibérico que en otros ejemplos propongo interpretar como un simbolo de fecundidad. Pero podría también entenderse como una prolongación de las líneas onduladas que constituyen la corriente del río, al modo de una figuración teriomorfa de aquél, es decir su arranque, su origen. Hemos hablado ya, con relación a los pegasos ampuritanos, de la naturaleza metamórfica del agua. Aquí es más difícil decidirse. En todo caso estamos ante un ritual de lustratio, de sacrificio a unas aguas que se pretende propiciar y fecundar con la sangre ritual del pequeño carnero escogido. No sabemos si la flor que sustenta esta escena simboliza a la naturaleza engendradora, como vimos en los vasos de Elche o de Liria. En este caso, como en tantos otros, nuestra distribución «aristotélica» de la naturaleza, basada en la jerarquización de los elementos de la anterior filosofia presocrática, no corresponde con la del ibero que superpone el agua sobre el soporte general de la flor, concibiendo ésta como brote que todo lo fecunda y dentro de una concepción cíclica: el varón fecunda con la sangre del sacrificio a quien a su vez le ofrece su fecundidad, el río y la flor. No es otra la justicia estricta que, como acto jurídico y cósmico, implica todo sacrificio. Pero estamos ante un bronce ibérico de rasgos formales marcadamente antiguos -el siglo $\mathrm{V}$ a. C., tal vez su primera mitad-y desde el período orientalizante es frecuente el esquema de soportes en forma de flor que sustentan cualquier motivo iconográfico. En este caso, por su carácter aislado, no podemos saber si existe una relación etiológica entre el elemento floral -enten- 
dido como fons et origo primordial-y los demás elementos: el manantial, el animal y el humano. De ser así -lo que, repito, no es seguro- el pensamiento lógico que aqui subyace sería el inverso al nuestro: la fuerza fecundadora de la naturaleza es tan intensa que motiva el brotar del agua $y$, además, el brotar del prótomo animal y el sacrificio, oficiado por el hombre, de la sangre caliente de la víctima animal. Éste tan sólo ofrece y devuelve a la naturaleza lo debido. Un aristotélico formularía la relación etiológica entre la flor y el río de una forma diferente. Por ejemplo: «el agua es $\tan$ fecunda que hace brotar a su paso la naturaleza vegetal». Lo que no es aquí el caso. Pero la interpretación de estos matices sobre la concepción ibérica de la physis deberia quedar abierta a las sugerencias y discusión de todos en el coloquio, si es que el tema lo merece. Muchas gracias.

\section{RESUMEN}

En este texto me ocupo de las referencias, textuales y principalmente iconográficas, sobre el culto a las aguas en las áreas tanto colonial - $-\mathrm{fe}$ nicios, griegos y púnicos-como ibérica de época prerromana en España. En el mundo colonial el culto a las aguas puede revestir una función múltiple -oracular, curativa, sagrada- La iconografía es el principal medio para acercarnos a la concepción del agua en el mundo ibérico. Pero es un documento ambiguo pues los símbolos revisten múltiples significaciones según el contexto.

\section{ABSTRACT}

In this paper I analyse the references -especially literary sources and iconography- dealing with the water cults in Preroman Spain. The scope of the research is limited only to the colonial areas such as Phoenicians, Greeks and Punics and, in the second part, to the Iberian one. In the coIonies this cult was endowed with a multiplicity of functions such as oracular, sacred and curatives powers. Iconography is the main way we dispose as an approach to the different notions of water amongst the lberians. But iconography is often vague and ambiguous, for symbols have a multiplicity of contextual meanings. 


\section{BIBLIOGRAFIA}

Almagro Basch, M. 1979: «Los orígenes de la toréutica ibérica» Trabajos de Prehistoria 36 , págs. 176-181, figs. 1-2.

Almagro Gorbea, M. 1978: “Los relieves mitológicos orientalizantes de Pozo Moro (Albacete)», Trabajos de Prehistoria 35, págs. 275-278.

Almagro Gorbea, M. 1983: «Pozo Moro: el Monumento Orientalizante, su contexto sociocultural y sus paralelos en la arquitectura funeraria ibérica», Madrider Mitteilungen 24, págs. 177-293, láms. 12-34.

AuBET, M. ${ }^{a}$ E. 1982: El Santuario de Es Cuieram. Ibiza.

BlÁzouez, J. M. ${ }^{a}$ 1957: “Aportaciones al estudio de las religiones primitivas de España», Archivo Español de Arqueología, 1957.

- 1959: «Los santuarios ibéricos de la provincia de Jaén», Oretania, 1, 2, 83 ss.

- 1975: Tartessos y los orígenes de la colonización fenicia en Occidente. Salamanca.

- 1977: “El culto a las aguas en la Península ibérica”, Imagen y Mito. Madrid, págs. 307331.

- 1983: Primitivas Religiones Ibéricas. Tomo II. Religiones Prerromanas, Madrid, 556 págs.

- 1991: Religiones en la España Antigua. Madrid, Ediciones Cátedra, 445 páginas.

Bonnet, C. 1988: "Melqart», Studia Phoenicia VIII. Leyden.

CHAPA, T. 1985: La escultura ibérica zoomorfa. Madrid.

CuRChIN, L. A. 1991: Roman Spain. Londres y Nueva York.

Domínguez MoReno, J. M. 1987: “Cultos a la fertilidad en Extremadura», Cuadernos populares. Mérida 1987.

D'onofrio, C. 1990: "La Bocca della Verità", en Un popolo di statue racconta. Roma, 302 páginas.

DIAZ DE VIANA, L. 1983: Romancero tradicional soriano. Soria.

DuNAND, 1971: «La piscine du trône d'Astarté dans le Temple d'Echmoun à Sidon», en BMB, 24, 19-25.

FaUth, W. 1979: «Asklepios», en Der Kleine Pauly, vol. I, cols. 644-648.

FERNANDEZ, M. 1992: “Pervivencia de los motivos ibéricos en la tradición popular», en La Sociedad lbérica a través de la imagen (catálogo de la Exposición, edit. OLmos, R.). Madrid, Ministerio de Cultura.

Garcia y Bellido, A. 1964: "Hercules Gaditanus», Archivo Español de Arqueologia, 36, págs. 70-153.

García y Bellido, A. y Fernandez de Avilés, A. 1964: Fontes tamaricas: Velilla del río Carrión (Palencia). Madrid 1964.

García y Bellido, A. 1975: Historia de España (edit. R. Menéndez Pidal), vol. I, 3.

García-Bellido, M. ${ }^{a}$ P. 1982: Las monedas de Cástulo con escritura indigena. Historia numismática de una ciudad minera. Barceloria.

- 1992: «La moneda, libro en imágenes, de la ciudad», en La Sociedad Ibérica a través de la imagen (catálogo de la Exposición, edit., Olmos, R.). Madrid, Ministerio de Cultura.

- 1992, en prensa: Comunicación en el Congreso Internacional, Griegos e Iberos, siglos viN, Ampurias, abril 1991 (en prensa).

- 1990: El Tesoro de Mogente y su entorno monetal. Valencia, págs. 168 y VII láms.

Gil Mascarell, M. 1975: "Sobre las cuevas ibéricas del pais valenciano. Materiales y problemas", Papeles del Laboratorio de Arqueologia de la Universidad de Valencia, n. "11, págs. 181-232.

- 1977: «Excavaciones en la cueva ritual ibérica de Villagordo del Cabriel (Valencia)», XIV Congreso Nacional de Arqueología, Vitoria, 1975. Zaragoza, págs. 705-712.

Hachuel, E. y MaRI, V. 1988: El Santuario de la llla Plana (lbiza). Una propuesta de análisis. lbiza.

JenkINS, G. K. 1972: Monnaies grecques. París.

JUARISTI, V. 1944: Las fuentes de España. Madrid. 
Llobregat, E, 1981: "Toros y agua en los cultos funerarios ibéricos", Saguntum, 16, págs. 149-161.

LuCAS, M. ${ }^{a}$ R. 1981: «Santuarios y dioses en la Baja época ibérica», en La Baja época de la cultura ibérica. Madrid 1981.

Mangas, J. et alii, 1991: Hispania Epigraphica 2, 1990. Madrid.

MASSERIA, C. en prensa: «ll Santuari, La Lucania», Congreso Italo-español Komedón Zontes, San Giustino, 2 octubre de 1991.

MENICHETTI, M. 1988: “Le aristocrazie tirreniche: aspetti iconographici» en Storia di Roma 1: Roma in Italia. Torino.

Morena López, J. A. 1989: El Santuario Ibérico de Torreparedones, castro del Rio-Baena. Córdoba.

MoRKHOLM, O. 1991: Early Hellenistic Coinage, from the ascension of Alexander to the peace of Apamea (336-186 B. C.). Cambridge University Press.

Ninck, M. 1921: «Die Bedeutung des Wassers im Kult und Leben der Alten», Philologus, Supp/band. 14.2. Leipzig.

Olmos, R. 1988: «El Casco Griego de Huelva» en El Casco Griego de Huelva, págs. 39-79.

- 1989; "Los griegos en Tartessos: una nueva contrastación entre las fuentes arqueológicas y literarias", en Auget Semmler, M. ${ }^{2}$ E., (edit.) Tartessos. Barcelona, editoria! Ausa.

- 1989 b: «Míticos pobladores del mar», Lecturas de Historia del Arte, Ephialte, vol I, 1989, págs. 23-62.

_- 1990: "Original Elements and Stimuli in Iberian Pottery, Part 2", Mediterranean Archaeology, vol. 3 , págs. 7-25, láms. 7-17.

Olmos et alii, 1992: La ciudad ibérica a travès de la imagen. Catálogo de la Exposición. Ministerio de Cultura, Madrid.

Orlandini, P. 1968-69: «Disffusione del culto di Demetra e Kore in Sicilia», Kókalos, XIV-XV.

PENA, M. ${ }^{2}$ J. 1973: "Artemis-Diana y algunas cuestiones en relación con su iconografia y su culto en Occidente, A) El culto federal de Diana; B) El problema de la Artemis emporitana", Ampurias, XXXV, págs. 109-134.

- 1987: "Los thymiateria" en forma de cabeza femenina hallados en el N.E. de la Peninsula Ibérica», Grecs et ibères au Ive. s. avant Jésus Christ. Revue des Études Anciennes, LXXXIX, 1987, 3-4, págs. 349-359.

PERICOT, L. 1979: Cerámica ibérica, Barcelona.

Pla E. y Lacomba, E. 1980: Los Villares (Caudete de las Fuentes, Valencia) Valencia. Publicaciones del S.I.P., vol. n. 68 .

Ramos FennÁndez, R. 1989: "Nuevos hallazgos en La Alcudia de Elche", Archivo Español de Arqueologia, 62, págs. 236-240.

Ruiz Bremon, M., 1987: Los exvotos del santuario ibérico del Cerro de los Santos, Albacete.

Ruano, E. 1988: “El Cerro de los Santos (Montealegre del Castillo, Albacete): una nueva interpretación del santuario», Cuadernos de Prehistoria y Arqueologia de la Universidad Autónoma de Madrid 15, págs. 253-273.

Ramos Fernández, R. 1989: «Nuevos hallazgos en la Alcudia de Elche», Archivo Español de Arqueologia, 62, págs. 236-240.

Rulz Galvez M." L. 1985: "Nueva espada dragada en el Río Ulla. Armas arrojadas a las aguas", en Homenaje a Alfredo García Alén. Pontevedra.

Shefold, K. y Jung, F. 1989: Die Sagen von den Argonauten, von Theben und Troia in der klassischen und hellenistischen Kunst. Munich, 427 páginas.

Schulten, A. 1943: "Forschungen in Spanien", Archäologischer Anzeiger, 58 págs, 19-33.

Toporov, V. N. 1973: "L' "albero universale". Saggio di interpretazione semiotica», en Ricerche semiotiche (edits. LotMAN, Jurii M. y USPENSKIJ, Boris A.). Torino, págs. 148-209.

VAQuerizo, D. 1990: «La Villa Romana de El Ruedo, Almedinilla, Córdoba», Archivo Español de Arqueologia, 63, 1990, 295-316.

VAldiVIESo OVEJERo, R. M. 1991: Religiosidad antigua y folklore religiosos en las sierras riojanas y sus aledaños. Biblioteca de temas riojanos. Logroño 1991, 112 páginas.

Villaronga, L. 1979: Numismática antigua de Hispania. Barcelona 1979 (reed. 1987). 